\title{
Perspective \\ Elaboration of a Phytoremediation Strategy for Successful and Sustainable Rehabilitation of Disturbed and Degraded Land
}

\author{
Lerato M. Sekhohola-Dlamini (D), Olajide M. Keshinro (D), Wiya L. Masudi (D) and A. Keith Cowan *(D)
}

check for

updates

Citation: Sekhohola-Dlamini, L.M.; Keshinro, O.M.; Masudi, W.L.;

Cowan, A.K. Elaboration of a Phytoremediation Strategy for Successful and Sustainable Rehabilitation of Disturbed and Degraded Land. Minerals 2022, 12, 111. https://doi.org/10.3390/ $\min 12020111$

Academic Editors: Yan Li and Jaume Bech

Received: 31 October 2021 Accepted: 18 January 2022 Published: 19 January 2022

Publisher's Note: MDPI stays neutral with regard to jurisdictional claims in published maps and institutional affiliations.

Copyright: (c) 2022 by the authors. Licensee MDPI, Basel, Switzerland. This article is an open access article distributed under the terms and conditions of the Creative Commons Attribution (CC BY) license (https:/ / creativecommons.org/licenses/by/ $4.0 /)$.
Institute for Environmental Biotechnology, Rhodes University (EBRU), Makhanda 6140, South Africa; sekhoholalerato0@gmail.com (L.M.S.-D.); olajidekeshinro@gmail.com (O.M.K.); desamunya@gmail.com (W.L.M.) * Correspondence: a.cowan@ru.ac.za; Tel.: +27-79-902-2457

\begin{abstract}
Humans are dependent upon soil which supplies food, fuel, chemicals, medicine, sequesters pollutants, purifies and conveys water, and supports the built environment. In short, we need soil, but it has little or no need of us. Agriculture, mining, urbanization and other human activities result in temporary land-use and once complete, used and degraded land should be rehabilitated and restored to minimize loss of soil carbon. It is generally accepted that the most effective strategy is phytoremediation. Typically, phytoremediation involves re-invigoration of soil fertility, physicochemical properties, and its microbiome to facilitate establishment of appropriate climax cover vegetation. A myco-phytoremediation technology called Fungcoal was developed in South Africa to achieve these outcomes for land disturbed by coal mining. Here we outline the contemporary and expanded rationale that underpins Fungcoal, which relies on in situ bio-conversion of carbonaceous waste coal or discard, in order to explore the probable origin of humic substances (HS) and soil organic matter (SOM). To achieve this, microbial processing of low-grade coal and discard, including bio-liquefaction and bio-conversion, is examined in some detail. The significance, origin, structure, and mode of action of coal-derived humics are recounted to emphasize the dynamic equilibrium, that is, humification and the derivation of soil organic matter (SOM). The contribution of plant exudate, extracellular vesicles (EV), extra polymeric substances (EPS), and other small molecules as components of the dynamic equilibrium that sustains SOM is highlighted. Arbuscular mycorrhizal fungi (AMF), saprophytic ectomycorrhizal fungi (EMF), and plant growth promoting rhizobacteria (PGPR) are considered essential microbial biocatalysts that provide mutualistic support to sustain plant growth following soil reclamation and restoration. Finally, we posit that de novo synthesis of SOM is by specialized microbial consortia (or 'humifiers') which use molecular components from the root metabolome; and, that combinations of functional biocatalyst act to re-establish and maintain the soil dynamic. It is concluded that a bio-scaffold is necessary for functional phytoremediation including maintenance of the SOM dynamic and overall biogeochemistry of organic carbon in the global ecosystem
\end{abstract}

Keywords: coal; bioconversion; bioremediation; humic substances; opencast; phytoremediation; spoil; discard dumps; rehabilitation

\section{Introduction}

Land-use for primary activities such as human settlement, industry and mining often times competes with and threatens regional food security and natural water sources as it consumes arable soil which is far better purposed for agriculture. In South Africa, the majority of large coalfields that are expected to be mined long into the future are located in the Mpumalanga Province [1,2]. As in many coal-producing regions of the world, the Emalahleni coalfields of Mpumalanga Province occur together with almost half of South Africa's high potential arable land [3], which is utilized for large-scale row-crop farming of cereal grains and oilseeds [4,5]. Since most soils in South Africa contain less than $0.5 \%$ organic carbon with only $4 \%$ of arable soils, at $2 \%$ or more [6,7], any increase in coal mining emphasizes the threat posed by this activity to crop production and food security. This is 
further emphasized by a recent estimation that global agricultural land-use has created a soil carbon deficit of $133 \mathrm{Pg} \mathrm{C}$ [8]. Moreover, in 2012, it was established that, using current rates of coal mining in the Mpumalanga Province, if sustained, about $12 \%$ of South Africa's total high potential arable land would be transformed to mined land, while a further $13.6 \%$ would be subject to prospecting [5], which would likely exacerbate land disturbance and soil C loss.

The combined impact of mining and prospecting on vegetation, soil structure, and soil microbial community affects both natural vegetation and future land-use. For example, high-impact disturbances such as mining tend to increase the rate of introduction of invasive species and the abundance of some, post-introduction [9]. Furthermore, mining and related activities necessitate clearance of vegetation, causing loss of soil and soil microflora, as well as the seed bank, compaction, decreased soil water absorption, and acidification [10]. As a result, the cost includes regional deterioration of water and soil quality, loss of biodiversity, and increased risk to human health [11,12]. Indeed, the competition for land-use between mining and agriculture is likely similar in most if not all coal-producing countries and has long been recognized as an unending challenge $[13,14]$. There is a growing recognition that soil quality is indeed important to human health [15]. Poor air quality with high particulate matter, a long-accepted consequence of coal mining and utilisation [16], is a major cause of respiratory diseases and in some areas has been reported to increase mortality of the most vulnerable [17]. So too, contamination of water resources and arable land directly impacts the water-energy-food nexus that is considered central to sustainable development [18]. Within the context of mining as a temporary land-use activity, there is a responsibility on mining companies to rehabilitate and restore used and often degraded land to a form that can sustain economic productivity, whether similar or different from previous use.

In situ rehabilitation is the preferred option for most mining companies $[10,19,20]$. While every instance is unique, the conventional method (at least in South Africa) has been the import and layering of topsoil to both re-create landform and cloak or mask subsoils and backfill to ameliorate negative impacts of carbonaceous material on the broader environment, and to support and promote the establishment of cover vegetation. To this end, disturbed land post-mining is covered in a layer of topsoil (usually $50-100 \mathrm{~cm}$ ), treated with lime to mitigate acid-generating potential of the substrate, appropriate fertilizers are applied, and the area is re-vegetated using selected annual and perennial species [21,22]. This approach is presumably based on common practice of applying a cultivable layer of soil, sourced from elsewhere, to enhance plant growth [23]. However, deposited layers of soil cannot effectively sustain plant cover year after year with limited humic matter which is depleted over time [24]. Not only does this practice limit rehabilitation, it also creates more environmental disruption. Furthermore, low nutrient content of applied soil coupled with accelerated mineralization of its organic matter reduces cation exchange capacity, which in turn reduces efficiency of fertilizers to supplement soil nutrient content [25]. As a consequence, revegetation is often sporadic, substrate compaction ensues, and cover vegetation eventually dies. This, coupled with a 'robbing Peter to pay Paul' approach in sourcing, acquisition, transport-sometimes over considerable distances — and eventual deposition of topsoil, has led to a strategy that is far from sustainable and outcomes that are mostly less than desirable. In addition, use of incompatible soils, often with poor organic content and lacking appropriate biotic components required for degradation of pollutants, and successful establishment of a 'technosol' to ensure sustainable revegetation, is either overlooked and/or omitted [26-28]. Indeed, and as stated by Šourková et al. [29], possibly the most important requirement for ecosystem rehabilitation in a post-mining landscape is soil development. For these reasons, detailed studies in our laboratory were initiated to derive a more holistic passive phytoremediation strategy for in situ restoration of land disturbed by coal mining [22,30-34]. The outcome: a phytoremediation technology developed for rehabilitation of South African coal discard dumps and mining-disturbed landscapes termed Fungcoal [35]. Fundamental to the Fungcoal rehabilitation process are: (1) microbial degradation of the carbonaceous pollutant, (2) bio-generation of a humic 
substance (HS)-rich technosol with increased organic matter content; and (3) promotion of plant-microbe mutualism, recruitment of beneficial rhizosphere microbes, and enhanced microbial activity.

In this manuscript and by way of example, we elaborate on the Fungcoal rehabilitation strategy developed in South Africa in an effort to elucidate a possible biological origin of humic substances (HS) and soil organic matter (SOM). Better known as bioremediation, biological processing is a branch of environmental biotechnology that employs living organisms such as plants and microorganisms to remove contaminants, pollutants, and toxins from terrestrial, aquatic, and other environs to stabilize, reinvigorate and restore affected systems. In deriving an appropriate bioremediation strategy for land disturbed by coal mining, we discuss briefly the environmental impact of coal mining and current land stewardship, the microbial bioconversion of coal and waste coal materials, and the role of arbuscular mycorrhizal fungi (AMF), saprophytic ectomycorrhizal fungi (EMF), plant growth-promoting rhizobacteria (PGPR), and plant-microbe mutualism in supporting successful and sustainable reclamation. We discuss in some detail the Fungcoal bioremediation protocol for successful long-term rehabilitation of coal-mining affected land and its return to a stable condition, capable of supporting permanent and productive use. Based on in situ transformation of coal discard to a HS-enriched soil-like substrate that supports plant growth and (re)vegetation, we postulate that $\mathrm{SOM}$, and hence fertility, is formed de novo by a specialized microbial consortium comprising 'humifiers', and that combinations of functional biocatalysts act to re-establish and maintain the soil dynamic. These 'humifiers' use molecular components from the root metabolome and, together with combinations of functional biocatalyst, act to re-establish and maintain the soil dynamic. It is concluded that holistic phytoremediation is therefore potentially more favourable, both financially and environmentally, for the sustained stabilization and restoration of disturbed land.

\section{Impact of Mining-Induced Land Disturbance and Appropriate Stewardship}

Coal mining has inevitable negative impacts on the environment, and once mineral extraction is complete, overlying spoil is typically returned to the void through a process known as backfilling [36]. Where backfilling is not possible, overburden together with residue from coal processing are stock-piled in huge undulating heaps called discard dumps [17,37]. Such handling and management of coal waste have both short- and longterm environmental impact (Figure 1). Particulate matter from these non-aesthetic, highly engineered structures contributes directly to deterioration of air quality, while stockpiled material is a potential source of pollutants that contaminate adjacent terrestrial and aquatic ecosystems. Run-off of water from discard dumps dissolves loosely bound toxic metals from waste coal that pollute nearby water bodies. Where a dump comprises high pyritecontaining waste, surface water reacts with iron sulphide to become acidic [38,39]. The reaction generates acid mine drainage that infiltrates surrounding soil and water bodies and can eventually reach the water table and contaminate underground water sources [39]. Many dams and major river systems occur in the coal-mining regions of South Africa and mining activities pose a serious pollution threat to these national watercourses and thus provision of potable water [40]. 


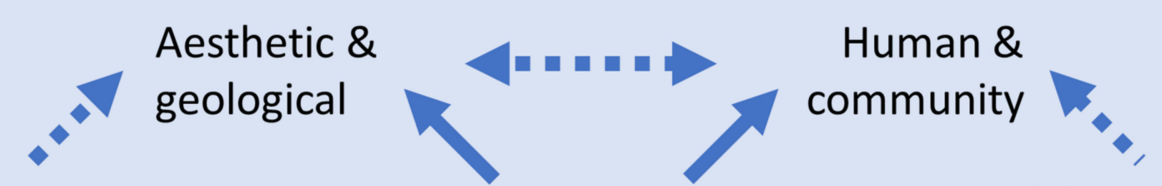

Mined void / goaf

- Spontaneous combustion

- Acid mine decant

- Compaction / subsidence

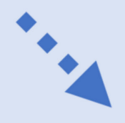

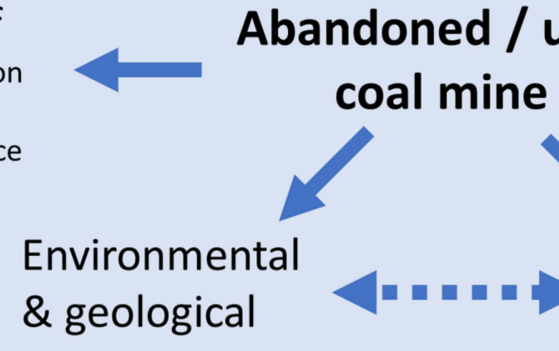

Discard dumps

- Spontaneous combustion

- Dust \& particulate matter

- Erosion \& collapse

- Acid mine leachate

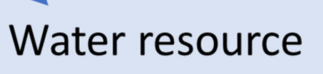
\& groundwater

Figure 1. Diagrammatic representation of the immediate, direct (solid arrows) and long-term, indirect impacts of mining and stockpiling of waste coal and coal discard on the environment; adapted from Li et al. [41] and Agboola et al. [42].

Although coal dumps and overburden (also called spoil) are known to self-rehabilitate without human intervention, this depends on a number of factors and can take decades to effectively minimize or negate any deleterious environmental impact [43]. Often, because of high temperatures, spontaneous combustion occurs, and a high clay content, poor substrate porosity and aeration, waterlogging, and a heteromorphous structure can combine to make it difficult for cover vegetation to succeed [38,44-46]. Post-mining rehabilitation processes therefore involve covering disturbed land and discard dumps with layered topsoil for cultivation of perennial vegetation to bind and stabilize the waste material, reduce dust-generating potential, and restrict ingress of oxygen and water to minimize erosion, acidic decant, and loss of sediment [21]. However, more often than not, this approach is constrained by specific challenges including acidification of the layered soil due to up-flow of acidic decant formed gradually from underlying discard. Nevertheless, a new anthropic soil or 'technosol' can be generated either after backfilling mined land through a superficial application or by the layering of an oftentimes highly weathered (oxidized) and leached overburden that was stored for periods up to several decades. To this material, a series of management guidelines is applied to give structure and stability to the new substrate and to ensure plant growth and establishment of cover vegetation. In many cases, this is easily achieved using available or imported topsoil which is layered, in some examples, up to a depth of $0.5 \mathrm{~m}$ [22]. Even so, agents that help to structure and generate soil-like aggregates within these technosols are required and include those that introduce organic matter $[34,47]$. Thus, it is imperative that mining companies incorporate sound rehabilitation strategies into the day-to-day operations rather than leave disturbed land and discard dumps to natural intervention. However, a major omission in developing rehabilitation strategies in the past has been the absence of biotic factors required for sustained and successful re-vegetation of mining-disturbed land.

Most human activities including coal mining alter and, in some cases, destroy regional topography and disrupt all of the components of soils including the horizons and structure, microbial populations, and nutrient cycles that are central to sustaining ecosystem health. All ecosystems function optimally as a set of processes that depend on nutrient recycling, which is the balance between the growth and decomposition of organic matter. Soil provides the scaffold to sustain this process, so its structure, composition and density directly affect the establishment, composition, and stability of the dominant plant community post-rehabilitation. Reshaping surface land after mining ends may render a natural-looking landscape, but the replaced soils will not be the outcome of typical evolutionary development. Soil components will have been negatively impacted by practices associated with 
coal mining such as topsoil removal followed by either long-term storage or stockpiling during the mining process, subsequent spreading of an aged, stored soil once mining activities have ceased, and the status post-spreading including usage of remotely sourced topsoil. Thus, reclamation must utilize strategies that improve soil structure, microbe population, and nutrient availability to revitalize the mined land from a situation of highly disturbed to a repaired condition capable of self-sustaining function.

Indeed, convincing reasons to share the definition of rehabilitation proposed by Coppin [48], as the conversion of land from some original status, through mining, to a new and beneficial condition, have recently been reiterated [49]. The process, it is suggested, must return land to a stable condition, capable of supporting permanent and productive use. At the same time, newly restored land must allow for different land-use opportunities, mitigate against environmental deterioration, and resemble the surrounding landscape which may be very different from its historical state. While land disturbed by mining can apparently "quickly restore itself" naturally [43], whether such natural rehabilitation processes repair and re-invigorate land for viable post-mining agriculture or forestry is largely unknown or at best, poorly documented. A retrospective account of the key priorities in the rehabilitation of mined land in Australia recognized that emergence of open cast mining had increased the footprint of the environmental disturbance, which in turn accelerated the evolution in rehabilitation priorities of that country [50].

\section{Biological Processing of Coal and Coal By-Product}

Many countries will, in the absence of alternative energy solutions, continue to rely primarily on coal due to the financial cost of purchasing crude oil and petroleum imports. Conventional combustion of coal is, however, detrimental and contributes to greenhouse gases (GHG) which exacerbate climate change. The development of 'cleaner' coal technology has therefore become imperative for the continued use of this vast resource. The term clean coal technology, first used in 1987 (U.S. Senate Bill 911, April 1987), refers to any technology deployed at either a new or existing facility that will substantially limit emissions of sulphur dioxide and/or oxides of nitrogen from the combustion of coal in the generation of electricity. For example, using additives to minimize the production of sulphur dioxide, conversion of coal to methane for use as a fuel, along with beneficiation of coal discard to value-added products, offer much cleaner alternatives.

Coal mining generates megatons of low calorific residue and by-product, sometimes referred to as discard, that is not considered marketable. Several possibilities exist for the implementation of cleaner coal technologies in which low calorific brown coals and coal discard might be either upgraded in energy value or serve as substrates for the generation of methane, geopolymers and other value-added products. Discussed in subsequent paragraphs are some of the principles and practices that underpin various biotechnologies that have been developed for purposes of managing waste coal and discard and to beneficiate or valorise this by-product in order to mitigate pollution and land deterioration.

\subsection{Coal Bio-Liquefaction}

Bio-liquefaction or biosolubilization affords potential to convert all ranks of coal, coal discard, coal fines, and waste coal into products potentially useful for cleaner energy and/or for creating a platform for novel bioprocess development and production/refining of complex aromatic compounds [30,51,52]. More than 20 years ago, the outcome of an initiative to address cost advantages of using solubilized lignite as a liquid power-generation fuel, due to emergent use of smaller boilers, simplified fuel handling, and a nearly ash-free fuel that produces almost no sulphur emissions, was published as part of a study undertaken by the German coal company, Rheinbraun [53]. In 1997, very little was known about the mechanism of coal bio-solubilization by microorganisms. Nevertheless, one study showed that the ability of the fungus Fusarium oxysporum to solubilize coal was constitutive, whereas for Trichoderma atroviride, the process was inducible [54]. Another study revealed the likely presence of a ligninolytic enzyme system in Fusarium oxysporum and Trichoderma atroviride 
comparable to that of the wood-rot fungus Phanerochaete chrysosporium [55], which was believed to involve, at least in part, both manganese peroxidase and lignin peroxidase [56]. In 1999, the fungus Trametes versicolor was shown to decolourize coal-derived humic acids (HA) and in the process, produce a large amount of laccase [57]. Later, in 2008, the fungal liquefaction of hard coal by Neosartorya fischeri was demonstrated [30]. The first confirmation that a laccase (LAC, E.C. 1.10.3.2) was directly involved in fungal biosolubilization of coal was subsequently reported for this isolate [33]. To date, LAC remains the only candidate enzyme identified and functionally characterized from a coal-degrading fungus. Thus, heterologous expression of a Fusarium oxysporum LAC in the yeast Pichia pastoris was shown to depolymerize and liquefy solubilized brown coal with the release of humic and fulvic acids [58,59].

Another coal-solubilizing enzyme thought to be involved in coal liquefaction or biosolubilization appears to be esterase. Typically, esterases are hydrolase enzymes that split esters into an acid and an alcohol residue in a chemical reaction with water, i.e., hydrolysis. The first indication that an esterase activity might be involved in coal biosolubilization was from studies on bacterial depolymerization of HA-derived from lignite [60]. Although a lignin peroxidase from Penicillium chrysosporium was considered to possess esterase activity [61], and addition of lignite to medium containing a coal-degrading isolate of Trichoderma atroviride enhanced extracellular esterase activity, it did so without any real evidence for its involvement in coal solubilization [62]. Cultures of Penicillium decumbens P6 were also shown to depolymerize lignite and early work suggested that both peroxidases and esterases were involved [63]. Later studies confirmed, albeit tentatively, that an esterase activity that had been partially purified using ammonium sulfate precipitation, anion exchange and gel filtration chromatography was able to convert lignite to low-molecular-mass HA with lower-percentage aromatic carbon but higher-percentage aliphatic carbon [64]. As pointed out by Sudheer et al. [65], in their detailed assessment of biological mechanisms for green coal utilization, esterases are not typically activated by mediators and steric hindrance will likely prevent the enzyme from accessing the depths of the coal macromolecule limiting its hydrolytic action. Further research encompassing the role of esterases, as well as recombinant gene technology, is needed to determine precisely the role by which esterases solubilize and liquefy brown coals and coal discard.

Other microbial enzymes implicated in biosolubilization and/or bioconversion of coal that deserve further study include cytochrome P450 mixed-function oxygenases [66] and cellulase and xylanase [67].

\subsection{Bio-Conversion of Coal to Methane}

Another approach that has demonstrated the microbial conversion of coal, and with the potential to mitigate environmental degradation due to stockpiling of discard and coal tailings, is bio-gasification of these by-products. Coal bio-gasification is a complicated biological process that utilizes the bioconversion potential of bespoke consortia of anaerobic microorganisms that have been enriched and are capable of degrading a mix of complex hydrocarbons [68-72]. Many laboratory studies have tended to focus on the bio-gasification of low-rank coal [73]. These coals contain readily leachable low molecular weight organics that may be susceptible to microbial degradation $[73,74]$. High-rank coals such as bituminous coal and anthracite, by comparison, comprise condensed polymeric aromatics that are not readily amenable to bio-gasification. However, a number of studies show that these higher rank coals may indeed support the growth of methanogens, albeit with relatively low yield [75-77]. Jones et al. [78] identified process factors that may enhance coal bio-gasification including increased bioavailability of carbon in coal, and development and inclusion of highly enriched bacterial consortia capable of degrading coal, establishing reaction conditions that promote microbial growth and function through increased nutrient supply and by the necessary cofactors and precursors, and by removing or neutralizing inhibitory factors. Microbial consortia able to degrade low-rank coals have been sourced from a range of environments including used and abandoned coal pits, underground coal 
seams and surrounds, aquatic sediments, petrochemical processing plant effluent, insects, cow dung, and domestic and industrial wastewaters have also been isolated [73,78-88]. So too, consortia of methanogens, and these have been shown to convert coal and coal waste products to methane and $\mathrm{CO}_{2}$ [84,87-90]. Indeed, it was recently demonstrated that a thermophilic archaeon isolated from oil-production water and identified as Methermicoccus shengliensis was able to bio-convert many types of methoxylated aromatic compounds (MACs) to methane, including MAC-containing coals [91]. Additionally, organic matter in various coal slimes can be reduced preferentially via $\mathrm{CO}_{2}$ to methane [92]. Together, these studies emphasize the potential of using anaerobic fermentation to further explore cleaner coal technologies.

\subsection{Humic Substance Production}

An additional processing technology is production of HAs or humic substances (HS) from low-grade coal. From a geological perspective, coal types fall into two categories and are either humic coals, developed from peat, or sapropelic coals, developed from organic mud [93]. Even so, in the early 1960s, low-rank coal was recognized as potentially a good feedstock from which soil amendments and organic fertilizers can be produced ([94] and references therein). Thus, lignites and other brown coals are more often used than high-rank coals as substrates to 'chemically' prepare HA-rich substances for use as soil amendments. Surprisingly, the type of parent coal is seldom considered, which must impact suitability of the purposed substrate. Nevertheless, HA-rich amendments are typically produced from low-rank coal as alkali-soluble humate salts [95-98]. Other methods for producing humics include solvent extraction and yield N-rich ammonium nitro-humates [99] and ion-free acid-precipitated humates [100]. Interestingly, lignite extraction with hydrogen peroxide appears rather selective and produces a material rich in malonic and succinic acids [101]. In contrast to the purported beneficial effect of humics on plants, malonic acid seems toxic and appears to negatively impact the growth and metabolism of Arabidopsis thaliana seedlings [102].

During the past decade, there has been increasing use of various biological catalysts, mainly fungi and bacteria, to convert low-rank coal into humic substances. Whereas fungi appear to utilize a suite of ligninolytic enzymes to degrade coal, and in particular LAC (see above), an early study showed that bacteria relied upon the production of surfactants, chelators, and/or alkaline substances [103]. More recent studies have reported the oxidation and degradation of low-rank coals by bacteria $[66,83,85,86,104-106]$ and fungi $[51,52]$ demonstrated improvement of edaphic materials by in situ formation of HS [47], and showed that some coal-degrading bacteria display traits typical of plant growth-promoting rhizobacteria [107].

Coal that has high ash content and other impurities has restricted use in energy generation. However, high availability and low price per ton are indeed motivators for beneficiation of low-rank coal to HS and for these to be used in chemistry and agriculture [108-113]. For example, lignite, often referred to as brown coal, is a soft, brown, combustible, sedimentary rock formed from naturally compressed peat that accounts for around $40 \%$ of the global coal reserve. It is known to be an inferior fuel due to its low calorific value, high ash yield, and high content of both bound oxygen and moisture, and thus is unsuitable for direct combustion (Figure 2). However, due to its high organic and oxygen content, lignite is desired for development as a feedstock for value-added chemicals and products $[114,115]$. Such value-added products may include geopolymers from coal 'gangue' (defined as the solid waste discharged during coal mining and coal washing) and/or activated lignite [116-118], iron-containing humics-stabilized nanoparticles [114], and carbonic nanostructures $[119,120]$. 


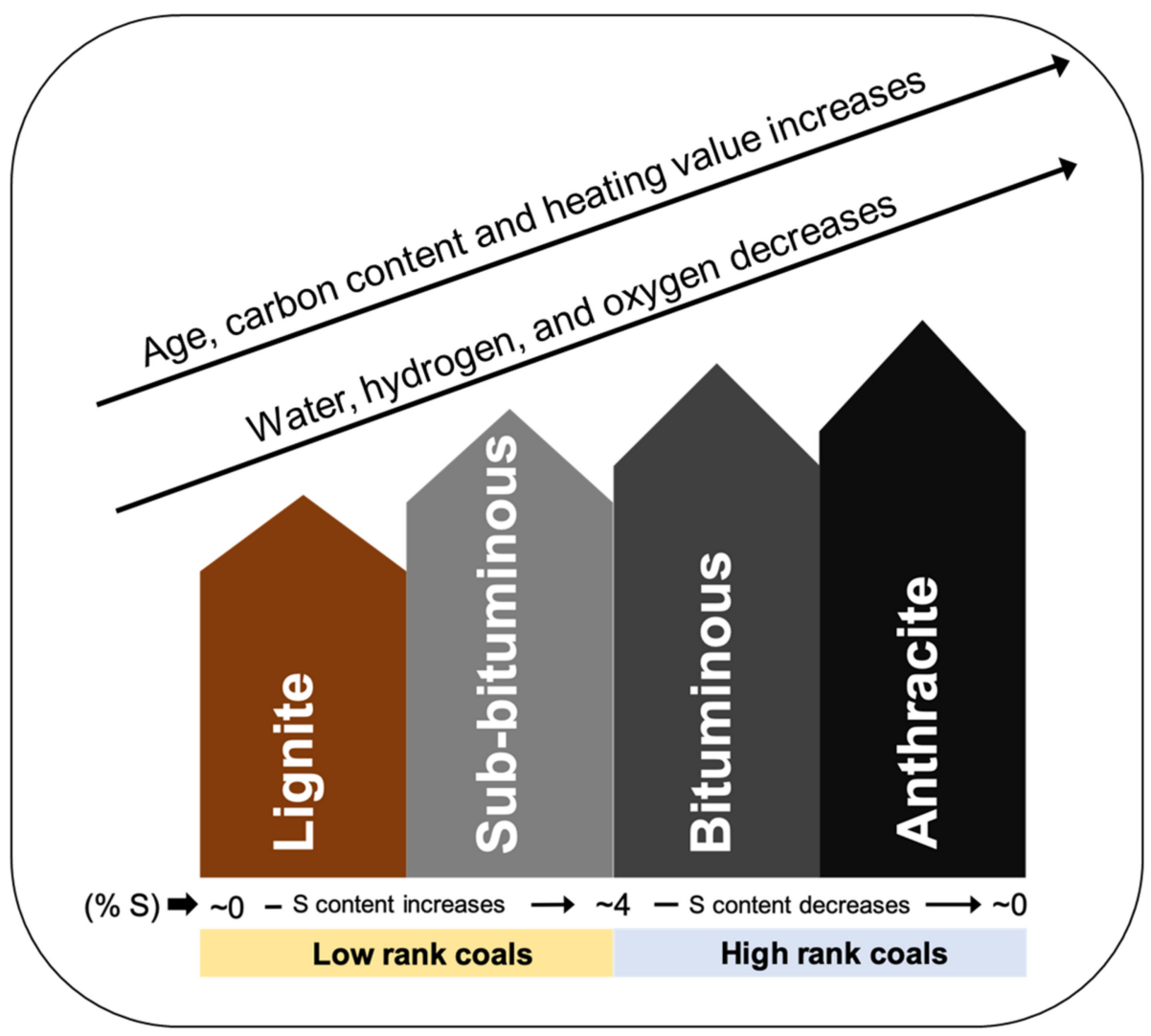

Figure 2. Illustration of the classification of coal types adapted from Sondreal and Wiltsee [121], American Society for Testing and Materials [122], and Mochida et al. [123].

Early work by Haider and Martin [124] showed that cultures of the ascomycete Epicocium nigrum produced HA in vitro, which was evidenced by the formation of polymers and disappearance of substrate phenols. A more recent study, using the lignite coal-depolymerizing bacterium Pseudomonas cepacia DLC-07, revealed that it first depolymerized and later polymerized a model lignin compound, and to a product of much greater molecular mass than the starting substrate [125]. Thus, and in contrast to lignite coal, which was significantly depolymerized, polymerization reactions dominated when a lignin-type molecule was used as substrate. Since microorganisms, like plants, actively produce aromatic compounds and exude these into the soil environment, soil microorganism-polymerized aromatics may indeed play a role in contributing to the formation and structure of HS-like aggregates.

The shikimate pathway is used by bacteria, archaea, fungi, algae, some protozoans, and plants to produce phenols, folates, and aromatic amino acids. This seven-step metabolic pathway commences with an aldol-type condensation of phosphoenolpyruvate (PEP) with D-erythrose-4-phosphate to give 3-deoxy-D-arabino-heptulosonic acid 7-phosphate, then quinic acid, and the key intermediate, shikimic acid. The latter condenses with PEP to ultimately give chorismic acid which arise by glyphosate-sensitive 5-enolpyruvyl-shikimate 3-phosphate synthase (EPSP-synthase)-catalyzed transfer of the enolpyruvyl moiety from PEP to shikimic acid 3-phosphate [126]. Thus, aromatics within SOM may originate either from black carbon (BC), which has its origin in a fire-affected organic matter [127], by decomposition of plant and algal material [128], directly from living plants via atmospheric emissions [129], and/or as components of root exudate [130-133]. Recently, 'functional bacteria' isolated from rice straw and provided appropriate oxidizing agents were shown to increase HS (measured as HA) concentration of compost, while the microbes showed elevated endogenous shikimic acid content and increased expression of 3-deoxy-7-phosphoheptulonate synthase, 3-dehydroquinate synthase and shikimate ki- 
nase $[134,135]$. Studies using the $\beta$-lactam amoxicillin, an inhibitor of transpeptidation in cell wall synthesis, support a role for bacterial community structure in HA formation [136]. Additionally, Actinobacteria are considered among the main drivers of lignin breakdown and humification during compost production, a process seemingly dependent upon enhanced LAC expression and activity and formation of quinone-like substances [137,138]. In addition, a lytic polysaccharide monooxygenase-glucose dehydrogenase (LPMO/GDH) system has recently been implicated in lignin degradation and quinone redox cycling and appears to do so by increasing $\mathrm{Fe}_{3}{ }^{+}$-reducing activity, $\mathrm{H}_{2} \mathrm{O}_{2}$ production, and hydroxyl radical generation by an enhanced Fenton process [139]. These observations indicate a role for both LPMO and LAC in lignin breakdown and turnover which, together with HS processing by saprophytic fungi and some members of the Ascomycota [140], suggests that specific microbial consortia may indeed drive humification. Interestingly, both "transforming bacteria" and "processing bacteria" were recently recognized as core microorganisms in fulvic acid (FA) formation during compost humification [141].

Although tentative, the proposal by Kallenbach et al. [142] that accumulation of humics/fulvics and thus SOM occurs as an outcome of distinct microbial community activity, and that accumulation of microbial-derived SOM is greatest in soils with greater microbial abundances and more efficient biomass production, seems therefore to hold. Thus, and as so eloquently elaborated by Baveye and Wander [143] in their perspective on why the "new" view of HS is still considered novel after more than 80 years, ideas surrounding the structure and formation of HS as elaborated above appear to correspond very closely with the description of HS as defined by Waksman [144], who emphasised the intimate association that exists between HS and soil microorganisms.

\section{Phytoremediation: A Strategy for Successful and Sustainable Reclamation}

Any rehabilitation intervention strategy requires prior knowledge of the site to fully understand prevailing conditions and determine the extent of land deterioration; most of the time, the process begins with an evaluation of the soil and reclamation thereof. Included are: identification of factors limiting soil fertility, soil physicochemical properties, soil microflora, and the selection of appropriate plant species that, after due consideration of conditions, will be able to sustain successful long-term vegetation cover $[19,23,44]$. It is therefore pertinent to examine in some detail the rationale underpinning the design of rehabilitation strategies and to comment on progress being made in the development of these for successful and sustainable reclamation of land disturbed by coal mining.

In the late 1990s, phytoremediation was considered the use of green plants to remove or render environmental pollutants harmless [145]. Both organic and inorganic pollutants, present in either solid or liquid substrates, and air were targeted using one or a combination of phytoextraction, phytodegradation, phyto-stabilization, rhizo-filtration, and phyto-volatilization. By 2005, the concept of phytoremediation had grown to include plants and the use of plant-associated microbes for environmental clean-up, and was perceived as a cost-effective and non-invasive bioprocess remediation technology [146]. As stated by Masciandaro et al. [147], plants produce a rich microenvironment capable of promoting microbial proliferation and activity through organic materials, nutrients, and oxygen supply. More contemporary studies regard phytoremediation as a green biotechnology tool and a step towards the realization of sustainable rehabilitation practice [148] with application in different environments including air, water, and soil [149]. Furthermore, a conceptual phytoremediation value chain has been proposed [150]. Underpinned by process engineering, six tiers, i.e., phytoremediation and metal removal, biomass cultivation and supply, refining bioproducts, storage, distribution, and demand, are all used to inform a multi-criteria decision-making model to address phytoremediation-refinery value chains design. Proponents argue that the establishment of modelling frameworks offers a way to derive commercial benefit from a phytoremediation strategy through biomass-derived value-added products. Nevertheless, and as stated by Naylor et al. [151], soil microorganisms play a major role in cycling soil organic carbon (SOC) to support plant growth. 
Furthermore, these authors argue that soil microbiome stability is key and is a combination of resistance, resilience, and functional redundancy, which can be quantified to provide insight into the severity of disturbances, and by inference, the intensity of phyto-remedial action needed.

In light of the foregoing, it is clear that rehabilitation strategies must go beyond simply rendering a new landscape. By considering land as an integrated living system with functions both above and below ground, rehabilitation protocols should focus on strategies that rebuild soil structure by stimulation of appropriate soil microbial communities and promotion of function to re-establish nutrient cycles, SOM, and to ensure self-sustainability (Figure 3). In this iteration, microorganism assemblages should address a minimum of two related aspects: first, an ability to utilize polluting carbonaceous pollutants and/or coal discard as a source of energy to yield a HS-rich soil-like by-product; and second, to assist cover vegetation to capture both macronutrients (e.g., phosphorus, sulfur, nitrogen) and micronutrients by penetration of plant root cortical cells. Of course, the primary initiative is to secure necessary rhizosphere assemblages to facilitate accumulation of humics/fulvics and generation and re-generation of SOM to sustain plant growth and vegetation of the land to be remediated.

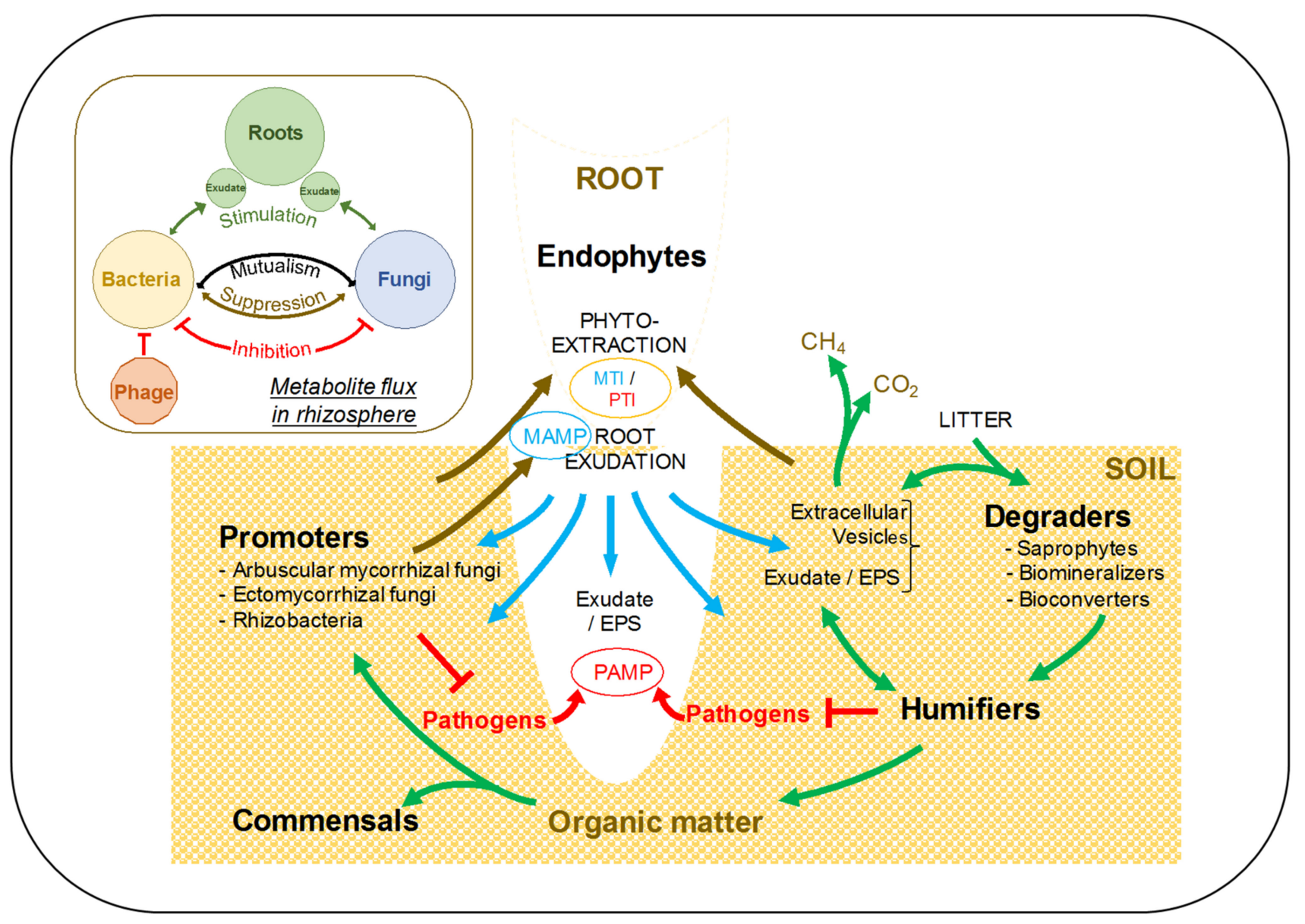

Figure 3. Plant-microbe interaction and metabolite flux in the rhizosphere. Fundamentals of a rehabilitation strategy to rebuild soil structure by stimulation of appropriate soil microbial communities and promotion of function to re-establish nutrient cycles, SOM content, to ensure self-sustainability. MAMP, microbe-associated molecular patterns; PAMP, pathogen-associated molecular patterns; MTI/PTI, MAMP/PAMP-triggered immunity; SOM, soil organic matter. Inset: Probable interkingdom molecular interactions/signaling in the rhizosphere adapted from [152]. 
A detailed account of rhizosphere control of associations between plants and microorganisms, the impact on biodegradation and bioavailability of organic and metalloid pollutants, and perspective on rhizosphere manipulation for management in the phytoremediation of soils, has been provided by Wenzel [153]. As stated by this author, multipolluted soils are complex and heterogenous which necessitates an integrated process for rhizosphere management in which a combinatorial approach of hydrocarbon- and/or coal-degrading microbes, co-cultivation of crops, and phytoextraction of pollutants is used to achieve the desired soil and land management outcomes.

In terms of disturbed and degraded land, enrichment of the substrate with a HScontaining soil-like material provides stable $\mathrm{pH}$, increases electrical conductivity and chelation potential, and provides structural support for biofilm formation which plays a crucial role in driving establishment of the necessary beneficial microbial populations and suppression of pathogen action. Of particular importance are AMF, which, together with EMF and/or PGPR, enhance root microbiome structure and dynamics and facilitate capture by plants of both macro- and micronutrients. Since AMF are believed to have contributed directly to evolution of vascular plants [154], it is not unreasonable to suppose that appropriate use of the required microorganisms will positively influence any phytoremediation strategy. This is particularly significant given that success depends on establishment of above-ground plant species of sufficient biomass with active root growth to support proliferation and activity of rhizosphere microbial consortia. Thus, together with root exudate driven metabolite-induced recruitment of microbial consortia [155], recognition of symbiont and pathogen-associated patterns, and enhanced plant disease resistance [156,157], and the overall contribution from the soil metaphenome [152], successful and sustained phytoremediation of mining damaged soils is possible.

\subsection{On the Origin, Supramolecular Aggregation, and Mode of Action of Humic Substances}

According to a 'new' 21st-century view [158-160], HS comprise a collection of diverse, relatively low-molecular-mass mostly aliphatic entities that exist as dynamic associations structured by both hydrophobic interaction and hydrogen bonding. As originally proposed by Piccolo and co-workers [161,162] and Nardi et al. [163], and since monomeric lipids apparently bind humics [164], it might be expected that associations organize into what appear to be micellar structures in appropriate aqueous environments. Structural characteristics, as determined by detailed NMR analysis, indicate a network of crosslinked polymeric substances that are complexed with metal ions to form aggregates. Thus, in contrast to earlier views on HS structure which persisted for most of the 20th century, a current view regards HS as neither aromatic nor recalcitrant but rather as an assemblage of largely aliphatic and carbohydrate-derived structures that during the humification process acquire some lignin-like structures $[128,165]$. However, and as stated by Trubetskoi and Trubetskaya [166], while a supra-molecular concept for HS structure is plausible, unequivocal elucidation awaits confirmation. These authors go further and entertain the possibility, based on intensive physicochemical analyses, that HS aggregates may indeed comprise vesicles, as initially proposed by Wershaw [167], and that during alkaline isolation, these structures either form or are released from organo-mineral complexes following degradation of the membrane layer. Likewise, Semenov et al. [168] concluded after a thorough evaluation of soil humification pathways that a supramolecular aggregation is more consistent with characteristics displayed by HS such as polydispersity, heterogeneity, amphiphilicity, dynamicity, and an ability to renew. It is also conceivable that vesicular aggregates that make up the bulk of HS organo-mineral material arise, in part, following release into the rhizosphere of plant- and microbe-derived extracellular vesicles $(\mathrm{EV})$ and/or exosomes.

Plants invest between 20 and $40 \%$ of photosynthetically-reduced C in root exudate [169]. While a number of studies indicate an interactive and regulatory role for compounds exuded, the bulk are primary metabolites and include sugars, amino acids, and organic acids that, together with soil micro-organisms, establish concentration gradients 
within the rhizosphere that modify root growth, interspecies interaction, and patterns of $C$ allocation $[170,171]$. Along with primary metabolites and bioactive secondary compounds, root exudate also appears to contain extracellular vesicles (EV). Small EVs have been isolated from roots of rice [172,173] and root exudate of tomato [174]. Proteomic analyses of these have identified several proteins known to be involved in plant-microbe interactions, and which inhibit spore germination and germination tube development of several pathogenic fungi. This suggests that EV released from plant roots may impact both inter-species communication and the root microbiome dynamic. Additionally, EV release from cell surfaces is a highly conserved process across the biosphere and is documented for archaea, bacteria, fungi (both mycorrhizal and non-mycorrhizal), and parasites [175]. Generally, EV are defined as lipid bilayer-enclosed, cytosol-containing vesicles released by the cell into the extracellular space, and presumably into the rhizosphere as well [176]. Plant, fungal and bacterial EV have been shown to contain an assortment of proteins, lipids, toxins, nucleic acids, pigments, polysaccharides, and enzymes [177-181].

Mechanisms involved in Gram-negative bacterial EV release are still not clear, but it is known that these carry cell wall hydrolases and peptidoglycan-degrading enzymes, whereas Gram-positive bacterial EV contain $\beta$-lactamases, hemolysin (hemolysin-like proteins in cyanobacteria [182], and toxins [183]. This suggests that Gram-negative bacterial EVs may be a source of cell wall-degrading enzymes that both facilitate EV release and cell wall metabolism. Fungal EV have also been shown to carry proteins, lipids, pigments, polysaccharides, and RNA which, taken together, represent virulence factors [181,183] and are known to contain enzymes and proteins including glucanase and glucanosyl transferase involved in cell wall turnover [179]. More importantly perhaps is that proteomic analysis of EV from the ascomycete Histoplasma capsulatum revealed the presence of a complex of proteins with multiple functions that included sugar metabolism, cell wall architecture, cell signalling, lipid metabolism, cell growth/division, and virulence [184].

In plants, EV appear to be entities designed to protect the materials being transported both inter-and extracellularly to support growth and development, defence against infection, and plant-microbe symbioses. In contrast, exosomes are considerably smaller than $\mathrm{EV}$ and range in size from 50 to $150 \mathrm{~nm}$ in diameter, and are formed after fusion of multivesicular bodies with the plasma membrane. Additionally, plant-derived exosome-like nanoparticles (ELNs) have also been characterized, and broccoli-derived nanoparticles were determined, from size distribution, to be on average $32.4 \mathrm{~nm}$ in diameter [185]. Although plant exosomes contain small molecules and proteins toxic to pathogenic fungi [186], their precise biogenesis remains obscure $[187,188]$ and the parts remain largely uncharacterized [176]. The situation for animal systems is much farther advanced, and in these a hypothetical pathway for vesicle biogenesis has been proposed [189]. The process involves, in brief, membrane microdomains that govern protein and nucleic acid accumulation, assembly, release of exosomes and/or ectosomes through regulated exocytosis, transport and/or targeting, interaction and fusion, deposition of luminal contents, reassembly, and eventual degradation or recycling. Precisely this process seems true for plant-derived exosomes. For example, the ability of compositional components of broccoli- and ginger-derived nanoparticles or exosomes to drive target specificity and impact human gut microbiome structure and function has been demonstrated $[185,190]$. Thus, there is no apparent reason why plant-derived exosomes should not also affect the root microbiome through interspecies communication, and in a similar way after release of EV into the rhizosphere, and recent studies seem to support this conjecture [191,192]. Indeed, it is very plausible that exosomes and other EV which are liberated from all three domains of life, viz. Archaea, Bacteria and Eukarya [193], contribute substrate to 'humification' which increases organic C content in what would otherwise remain an infertile non-living medium.

\subsection{Humification: A Dynamic Equilibrium That Sustains Soil Organic Matter}

Humic substances (HS) are deemed the major fraction of SOM and represent the outcome of a complex interaction between non-living organic matter and microbial commu- 
nities [194]. This complex interaction is often referred to as humification. One view defines humification as a phenomenon involving the transformation of dead organic matter into HS in which polysaccharides, but not lignin, is recycled via microbial metabolism [128]. It seems that the dynamic equilibrium between the pathways of humification and nonhumification stabilize SOM [168], and that humics lost from soil due to erosion, leaching, mineralization and/or assimilation are replenished by recycling of plant and algal matter [195]. Indeed, it has been suggested that all soil biomolecules, including the non-humic which cannot be separated without significant change in the chemical structure or chemical properties of the supra-molecular aggregate, should be considered part of the HS fraction [168]. Nonetheless, questions about the long-standing HS theory and an apparent role for these in stabilizing SOM remain. While the concept of HS has either been severely criticized and/or completely rejected [127,160,196], a recent perspective has embraced both the 'traditional' idea of HS and proposed a 'new' emergent view in which SOM is considered a continuum of progressively decomposing organic matter [197]. Why a continuum of decomposition and not a dynamic equilibrium? The latter being one in which the biological response to the decomposition of 'old' organic matter would undoubtedly be assimilation, synthesis, and assembly of 'new' but functionally distinct organic matter. A similar conclusion was reached by Gerke [127] in an appraisal of the views communicated by Lehmann and Kleber [197], which appeared to largely ignore the chemical or biochemical polymerization of aromatic sub-units and aggregation of these to give humic molecules. The latter is central to the concept of HS formation.

It is well accepted that abiotic mobilization of soil organic matter (SOM) can increase the rate of loss of $\mathrm{C}$ from the soil by the mineralization of HS. This typically occurs when the soil is either disturbed by erosion (e.g., wind and water) or clearance of vegetation for activities such as agriculture and mining. It also occurs in soil that has been stored in preservation banks until mining operations cease. In many cases, it is this 'dead' soil that is used first in rehabilitation efforts, and it is to this that organic matter must be returned. For managed fabrication of technosols from imported topsoil, carbonaceouscontaining spoil, overburden, and other materials, humification or the in situ biological production of HS and accumulation of humified organic matter is key [22,34,47]. Without humification, only two opposing processes are possible; either retention of the carbonaceous material or its continued mineralization to oxides. In both cases, the generation of the required technosols would be extremely difficult, if not impossible. Assuming humification does occur, carboxylate and phenolate functional groups in the HS macromolecule allow for complexes with $\mathrm{Mg}^{2+}, \mathrm{Ca}^{2+}, \mathrm{Fe}^{2+}$, and $\mathrm{Fe}^{3+}$ ions and the formation of chelates [198]. Hydrophobic bonds appear to hold the organic component of the humic molecules together and HS seem to behave as micelles in solution [161,162,199]. In addition, organic acids penetrate the humic micelle-like aggregate to re-arrange humic material and alter its biological activity by mobilizing molecules from the bulk soil [199]. In alkaline conditions, a negative charge develops which disrupts the high molecular size configuration and breaks these larger humic aggregates into small micelles. Such conformational properties of humic substances appear to be a function of $\mathrm{pH}$, and the concentration of organic acids which together contribute to the physical reclamation of soil [200], stimulation of microbial community activity [201], and promotion of plant growth and developmental responses [194].

A review of biological activity of HS at the soil-plant interface by Trevisan et al. [202] concluded that these substances show plant growth promoter-like activity and appear to stimulate cell division and differentiation. Indeed, early studies showed that coal-derived sodium humate stimulated root growth in some plant species and appeared to do this by promoting the formation of cell wall hydroxyproline and inhibiting peroxidase and indole3-acetic acid (IAA)-oxidase [95,203]. Additionally, HS stimulation of plasma membrane $\mathrm{H}^{+}$-ATPase activity was suggested to indicate increased susceptibility of plants to bioinoculants with concomitant modification of rhizosphere microbial community structure and activity [194]. These authors concluded further that changes in the biochemistry of 
energy generation and transport across the plasma membrane facilitated enhanced lateral root and root hair development. A role for HS in root physiology was again emphasized by results from a study that evaluated adventitious root formation using azalea microshoots [204]. In this study, humate increased the concentration of IAA and gibberellic acid (GA) in rooted shoots, whereas an increase in the concentration of other plant hormones, including zeatin riboside (ZR) and isopentenyl adenosine (IPA), occurred during the in vitro rooting process. Furthermore, HA increased the activity of a number of oxidases in humatetreated micro-shoots including peroxidase (POD), superoxide dismutase (SOD), ascorbate peroxidase (APX), catalase (CAT), and polyphenol oxidase (PPO). Some authors consider that HS exert an effect via conventional signalling cascades to trigger molecular and physiological responses [205], whereas others consider it a requirement to first obtain data on the spatial distribution of HS in tissues and cells to better understand how these substances impact plant physiology [206]. It is perhaps important to note that plant HA are structurally similar to those from soil, which suggests a probable plant origin [207]. Fluorescence spectrophotometry has revealed the formation of HA in senescent plants and algal matter before it reaches the soil [195]. Moreover, terrestrial plants and phytoplankton are known to emit an array of benzenoid compounds into the atmosphere and at rates that rival anthropogenic consumption of fossil fuels $[129,208]$. Whether these volatile secondary organics make any direct contribution to SOC content is not clear. Nevertheless, taken together, it seems plausible that replenishment, fortification, and preservation of plant-derived bio-macromolecules plays an important role in the 'humification process' and in the partitioning of fixed $C$ to soils.

In addition to using HS as soil amendment [209-212], to enrich root microbiome structure and health [213,214], to regulate plant growth [194,202,206,215-219], and as a eustressor [220,221], humics also contribute to green chemistry, control environmental pollution, and contribute substantially to improving global soil fertility and water quality [122]. For example, the use of HS appears to be a suitable remediation strategy for soils heavily contaminated with trace metals and other pollutants [222-226]; humics stabilize composted sewage sludge by interacting with metal and organic ions, and may control the fate of macro and micronutrients [227], and facilitate pollutant removal during water treatment [228-230]. One additional, less well-recognized use for HS is in flue gas desulfurization and denitrification for removal of $\mathrm{SO}_{2}, \mathrm{NO}_{\mathrm{x}}, \mathrm{CO}_{2}, \mathrm{H}_{2} \mathrm{~S}$, and heavy metals from waste gases [231]

\subsection{Mycorrhizal Fungi and Plant Growth Promoting Rhizobacteria: Essential Biocatalysts for Successful Phytoremediation}

Phytoremediation is a specialized form of bioremediation in which specific plants and their associated soil microbes are utilized to mitigate effects of pollutants and repair and rehabilitate disturbed land so that it can be reclaimed for some other beneficial and productive purpose. Among the associated soil microbes typically involved in phytoremediation are AMF, PGRB, and plant growth-promoting fungi (PGPF). It is accepted that symbiotic microorganisms such as AMF are very effective at enhancing ability of plants to establish and cope with prevailing conditions including fluctuations in water and nutrient availability, and these symbionts appear to do so by improving plant nutrient uptake and water relations. An important contribution in this regard is quantity and stability of soil aggregates that comprise soil particles, presence of fungal mycelia, roots, and carbohydrate-rich extra-polymeric substances (EPS) which help plants tolerate prevailing conditions [232,233]. In addition to AMF, some saprophytic fungi or PGPF also enhance plant performance and do so by affecting biotransformation of pollutants to less or non-toxic forms. For example, transformation of coal discard by a suite of coal degrading fungi and AMF to a humic-enriched soil-like material in the Cynodon dactylon/coal rhizosphere [34]. Even so, there is evidence that saprobic fungi and AMF are antagonistic, which can severely impact plant-microbe mutualism, and consequently, phytoremediation outcomes. Thus, germination and hyphal growth of Glomus mosseae were substantially reduced by Aspergillus 
niger, and the population of this saprobe decreased markedly following inoculation with the AMF, either simultaneously or two weeks later, but not when inoculated two weeks before inoculation with Glomus mosseae [234].

Both saprophytic fungi (and bacteria) and non-saprophytic EMF can be of benefit to plants and other microbes, particularly in low resource and pollutant-containing environments. Whereas AMF scavenge for nutrients released by saprotrophic microorganisms, EMF derive nourishment by utilizing dead and/or decaying organic matter [235]. Even so, content and composition of any rhizodeposition remain context-specific and dependent upon prevailing macrophytes and soil microbiota. While it is possible to distinguish between strategies of nutrient acquisition by estimating $\mathrm{C}$ and $\mathrm{N}$ isotope composition of various rhizospheric mycota [236], flux at the soil-root interface is bidirectional with both macronutrients being lost from roots and taken up from soil [170]. The relative contribution of these fluxes while clearly important remains ill-defined. Saprophytic fungi increase soil $\mathrm{pH}, \mathrm{N}$ and $\mathrm{P}$ contents, acid phosphatase and $\beta$-glucosidase activity [237]. In addition, the saprobe Neosartorya fischeri, together with other coal-degrading fungi and a suite of AMF, enhanced the oxidative bioconversion of waste coal to an HS-enriched soil-like material [34]. Additionally, co-inoculation using the AMF Funneliformis mosseae and the saprotrophic fungus Trichoderma viride alleviated oxidative damage in Triticum aestivum plants grown in a phenanthrene-contaminated soil [238]. Thus, combining AMF with appropriate saprophytic fungi does appear to have potential as a biofertilizer for soil restoration within the context of a phytoremediation approach.

Like PGPR, several species of fungi also produce plant growth regulators including gibberellins and auxins. Indeed, gibberellins were first identified from the ascomycete Fusarium fujikuroi [239] and both gibberellins and auxin are produced by AMF [240], EMF [241], and by the saprophytic pathogen, Leptosphaeria maculans [242]. In addition to phytohormone production, PGPR also produces siderophores and are capable of phosphate and potassium solubilization, and ACC deaminase activity [243], and several species appear to show coal degrading activity [107]. Of course, only three outcomes are possible from interactions between either AMF or EMF and PGP microbes, and these are: synergistic, antagonistic, and no response [244]. Positive effects of PGP microbes are likely either direct or indirect and achieved only following colonization of root surfaces. Direct effects on plant growth include biofertilization, growth stimulation, and mitigation of the impact of abiotic and biotic stressors, whereas indirect effects include disease reduction, antibiosis, induction of systemic resistance, and increasing nutrient availability [245]. Thus, it is perhaps not surprising that PGP microbes are touted to replace the use of chemical fertilizers in agriculture, horticulture, silviculture, and environmental clean-up strategies [243,246,247]. More extensive information about mycorrhizal fungal species as mediators of the outcome of inoculation, together with other beneficial rhizospheric microbiota, such as PGPF and PGPR on plant growth, root or rhizosphere colonization, disease suppression, and as biocontrol agents or biofertilizers, can be found in several extensive reviews [244,248-251].

\subsection{Towards Sustainable Rehabilitation: The Fungcoal Process}

From the above in-depth assessment of phytoremediation and associated contribution of humic-like substances and humification in soil establishment and fertility, and the essential role of PGPR and AMF, any new rehabilitation strategy must initially focus on rebuilding soil structure, recruiting and stimulating growth of soil microbial populations, and re-establishing nutrient cycles to ensure a sustainable outcome. The patented Fungcoal process was developed as a platform technology to address precisely these aspects and, with the major outcome: a novel technology for coal biosolubilization and beneficiation [35]. In brief, Fungcoal is based on mutualistic interaction between $\mathrm{C} 4$ grasses-such as Cynodon dactylon, Eragrostis tef, Pennisetum clandestinum, among others-root exudate, a suite of AMF including one or more of the following, Glomus clarum, Paraglomus occultum, Gigaspora gigantea and Glomus mossea, and at least one coal-degrading fungus, such as the isolates, $A s-$ pergillus strain ECCN 84 and/or Neosartorya fischeri strain ECCN 84. Developed as a strategy 
for rehabilitation of coal discard dumps and open cast spoil, the strategy exploits plantfungal mutualism to achieve biodegradation of any carbonaceous pollutant, and promotes reinvigoration of soil components and grass growth to sustain long-term re-vegetation.

In 2006, small-scale trials were initiated on a Roofcoal discard dump at Kleinkopje Mine, Landau Colliery, to determine whether the Fungcoal bioprocess indeed contributed to sustained rehabilitation, and to derive a protocol to ensure biological degradation and transformation of the carbonaceous substrate into a humic-enriched soil-like material capable of supporting vegetation. In 2012, hectare-scale trials were initiated on carbonaceouscontaining opencast spoil at Kromdraai Mine, Landau Colliery, to corroborate results obtained at a small-scale. While details of the experimental procedures from these trials are recounted elsewhere [22,34], a collage of the outcomes is presented in Figure 4.

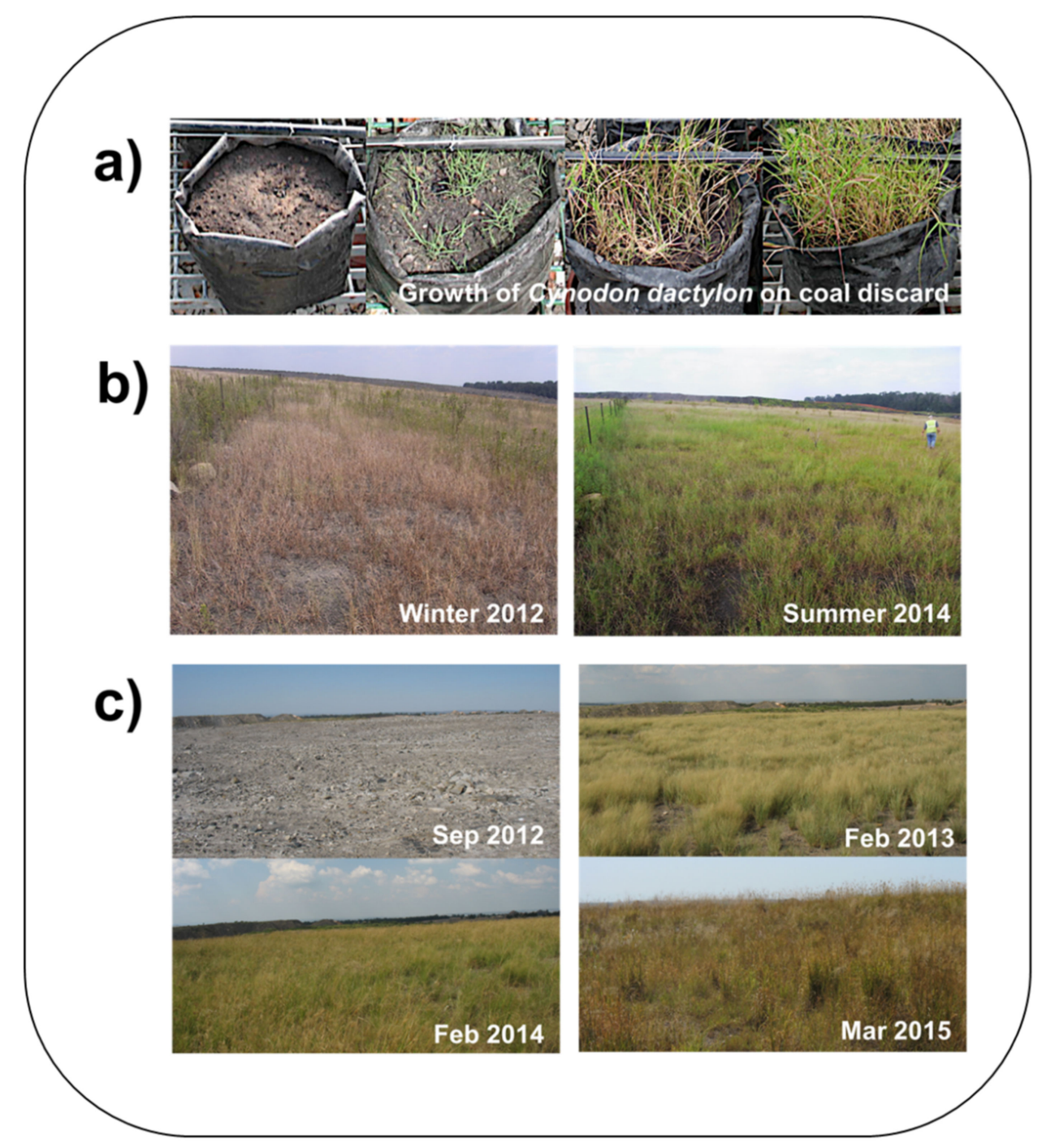

Figure 4. Photographs from studies carried out in South Africa by the authors laboratory illustrating successful re-vegetation of coal discard following application of Fungcoal technology. (a) In-season pot trial showing progression of Cynodon dactylon growth on coal discard; (b) re-vegetation at a smallscale $(20 \mathrm{~m} \times 20 \mathrm{~m})$ of a roof-coal dump in the Emalahleni Coalfield following application of Fungcoal (in early Summer 2006/7), planted with Cynodon dactylon, shown in winter (2012) and summer (2014); and (c) time course of re-vegetation at a hectare-scale of discard-containing open cast spoil at Landau Colliery (Kromdraai Mine), Emalahleni, following application of Fungcoal (September 2012) and seeded using a mix of Digitaria eriantha, Chloris gayana, Eragrostis tef, and Medicago sativa (5:5:4:2) applied at $20 \mathrm{~kg} / \mathrm{ha}$. For details of experiment, see Cowan et al. [22]. 
Pot trials, long-term small-scale field trials, and large-scale commercial scale application of Fungcoal monitored over several years confirmed successful in situ biodegradation of the carbonaceous pollutant, an increase in substrate HS content, and sustained cover vegetation without using outsourced topsoil (Figure 4). Fungcoal also improved substrate water holding capacity, reduced substrate ash content, and mitigated substrate acidification and salinity [22,34].

Informed selection of microbial and macrophyte biocatalysts appears therefore to be crucial for successful implementation of a phytoremediation technology, particularly given the importance of inter-kingdom interaction in the process [151,152]. Furthermore, while degradation of carbonaceous pollutants is clearly one objective [33,58,59,252,253], bacteria $[47,105,106,254]$, in particular PGPR [107], microalgae [255,256] and plants all participate in achieving the desired biotransformation and land restoration outcomes [31,32,34,51]. This inter-kingdom mutualism we posit is made possible by the suite of small molecules emanating from the phyllosphere and plant litter, microbial necromass, root exudate, and in situ substrate weathering, which together constitute the rhizosphere metabolome [257-259]. These agglomerated small organics serve as chemical signals that likely help recruit, stimulate, and coordinate microbial community structure, composition, and function. Indeed, the largest fraction of organic carbon entering the soil is from plant residues [257], and studies confirm that vegetation type and litter quality are major determinants of rhizosphere microbial activity [29] and soil fertility [260]. Earlier, we recounted information on structure and origin of HS and humification which, it was suggested, represents a dynamic equilibrium that sustains SOM. Given the outcome from Fungcoal applications, which support contention that accumulation of humics/fulvics and thus SOM is an outcome of distinct microbial community activity [142,143], as proposed originally by Waksman [144], we posit further that de novo synthesis of SOM is by specialized microbial consortia, which we have called 'humifiers', and which use molecular components from the root metabolome as substrate. Candidate bacterial humifiers may include the Actinobacteria with members of the Streptomyces, Proteobacteria (e.g., Devosia and Enterobacter) known to produce LAC and contribute to HS formation during composting [261], and members of the Sphingobacteriales, best known for their bioremediation potential, especially those from the family Saprospiraceae [51].

It has long been established that certain fungi are also strongly associated with promotion of humification [262,263]. Here, the saprotroph Trichoderma koningii, a common soil-dwelling fungus effective at colonizing plant roots and inhibiting disease-causing fungi, was shown to promote humification [262]. It was further deduced that humification commenced with the transformation of the smaller FA fraction, suggestive of the involvement of polymerization reactions. For waste coal, it is now accepted that the major route for fungal depolymerization of macromolecular coal is by LAC-catalyzed biosolubilization $[33,58,59]$ and that (re)-polymerization is necessary for humification to occur. The latter may be a function of plant-derived lignins and bacterial 'humifiers' which appear part of the polymerization process [60]. Indeed, the accumulation of an HS-rich soil-like material was attenuated in the absence of functional macrophytes [34], while bacteria isolated from microenvironments with high content of coal and/or hydrocarbon waste actively supported the formation of HS [66,85].

As elaborated above, it is generally accepted that plants enrich the microenvironment by exuding organics, nutrients, and supplying oxygen to promote growth and activity of soil microbes. In addition, it is the synergistic interaction between these organics, microorganisms and plants that is believed to ensure conservation of ecosystem integrity [147]. In this regard, addition of organic matter provides both readily accessible carbon and nutrients which, by a process termed bioaugmentation, accelerate the bioconversion and degradation of any contaminants. Furthermore, soils accumulate carbon when an increase in aboveground biomass is small and shed carbon when increases in plant biomass are high; moreover, associations of plants with mycorrhizal fungi appear to be key [264]. The latter is directly linked to plant nutrient acquisition strategies which, for most plants, are 
determined by actions of associated AMF. It is important to mention that in contrast to plant-AMF associations, plants that associate with EMF show higher aboveground biomass when exposed to elevated atmospheric $\mathrm{CO}_{2}$ [265]. Since AMF scavenge for nutrients released by saprotrophic microbes, whereas EMF mineralize nutrients from organic matter, a combination of both types of mycorrhizae would seem a necessary component in any phytoremediation protocol.

\section{Conclusions}

In this article, a recently developed strategy (i.e., Fungcoal), used to rehabilitate open cast spoil, re-vegetate mining disturbed land, and coal discard dumps, was elaborated in detail in an effort to establish the physicochemical characteristics of HS, how HS and SOM might arise, and the contribution of in situ humification to soil fertility. Taken together, the accumulated information seems to support ideas that soil microorganisms are indeed capable of either solubilizing or degrading coal discard and coal by-product to render a HS-rich soil-like residue that potentially serves as substrate for microbial humifiers and supra-molecular aggregation of HS into SOM via 'humification-like' processes. In this context, humification, or the in situ biological production of HS, represents a dynamic equilibrium wherein both "transforming" and "processing" microbes are core in assimilation and bio-conversion of components within the root microbiome and contribute directly to development of technosols capable of sustaining plant growth and re-vegetation. In addition to the contribution of substrate supplied by coal degrading saprobes (i.e., fungi and bacteria), mycorrhizal fungi, both AMF and EMF, and PGPR and fungi appear to be essential biocatalysts in phytoremediation. It is the overall direct and indirect input from the technosol metaphenome that ensures that successful and sustained rehabilitation of damaged soils and disturbed land is possible. Of course, macrophytes also play a critical role, and provide both readily accessible $C$ in the form of exudate and a supply of litter. Exudate, together with vegetation type and litter quality, seem to be major drivers of rhizosphere microbial activity, the promotion of metabolite-induced recruitment of appropriate microbial consortia, and the increase in HS content, SOM, and fertility. Thus, a functional bio-scaffold appears essential for maintenance of the SOM dynamic and overall biogeochemistry of organic carbon in the global ecosystem.

Development of sustainable technologies such as Fungcoal that reuse and recycle waste to generate functional technosols may significantly minimise the environmental land disturbance footprint. Furthermore, phytoremediation of land disturbed by activities such as mining using bespoke purposed technologies, such as Fungcoal, present an opportunity to transform not only that which is regarded in a linear economy as hazardous and of little value, but also degraded and disturbed land by providing a platform for in situ formation of HS and SOM to improve overall soil fertility and C sequestration activity. Additionally, in the case of coal mining-disturbed land, the reuse of spoil, coal by-product and coal discard may very well prove over time to be an approach, both financially and environmentally, that has the potential to solve many challenges in a post-coal world.

Author Contributions: L.M.S.-D. and A.K.C.: conceived and prepared the initial manuscript, reviewed edited versions, and prepared the final document; W.L.M. and O.M.K.: provided additional input and information, edited, and proof-read drafts of this perspective. All authors have read and agreed to the published version of the manuscript.

Funding: Rhodes University is acknowledged for support via RC Grant No. 02/2020 and 02/2021 to A.K.C., W.L.M. is supported by a doctoral grant from EBRU.

Data Availability Statement: Not applicable.

Acknowledgments: L.M.S.-D. and O.M.K. are grateful to EBRU for continued support.

Conflicts of Interest: The authors have declared no conflict of interest. 


\section{References}

1. Pone, J.D.N.; Hein, K.A.A.; Stracher, G.B.; Annegarn, H.J.; Robert, B. The spontaneous combustion of coal and its by-products in the Witbank and Sasolburg coalfields of South Africa. Int. J. Coal Geol. 2007, 72, 124-140. [CrossRef]

2. Eberhard, A. The future of South African coal: Market, investment, and policy challenges. Program Energy Sustain. Dev. 2011, 20, 1-30. [CrossRef]

3. Simpson, G.B.; Badenhorst, J.; Jewitt, G.P.W.; Berchner, M.; Davies, E. Competition for land: The water-energy-food nexus and coal mining in Mpumalanga Province, South Africa. Front. Environ. Sci. 2019, 7, 86. [CrossRef]

4. Bureau for Food and Agricultural Policy. The BFAP Baseline-Agricultural Outlook 2012-2021; BFAP: Pretoria, South Africa, 2012; p. 112. Available online: http:/ / www.bfap.co.za/wp-content/uploads/2018/08/BFAP_Baseline_2012.pdf (accessed on 16 March 2021).

5. Bureau for Food and Agricultural Policy. Evaluating the Impact of Coal Mining on Agriculture in the Delmas, Ogies and Leandra Districts: A Focus on Maize Production. Report Compiled for the Maize Trust; BFAP: Pretoria, South Africa, 2012; p. 47. Available online: https:/ / www.bfap.co.za/the-impact-of-coal-mining-on-agriculture/ (accessed on 17 March 2021).

6. Du Preez, C.C.; van Huyssteen, C.W.; Mnkeni, P.N.S. Land Use and soil organic matter in South Africa 1: A review on spatial variability and the influence of rangeland stock production. S. Afr. J. Sci. 2011, 107, 354. [CrossRef]

7. Du Preez, C.C.; van Huyssteen, C.W.; Mnkeni, P.N.S. Land use and soil organic matter in South Africa 2: A review on the influence of arable crop production. S. Afr. J. Sci. 2011, 107, 358. [CrossRef]

8. Sanderman, J.; Hengl, T.; Fiske, G.J. Soil carbon debt of 12,000 years of human land use. Proc. Natl. Acad. Sci. USA 2017, 114, 9575-9580. [CrossRef]

9. Calinger, K.; Calhoon, E.; Chang, H.-C.; Whitacre, J.; Wenzel, J.; Comita, L.; Queenborough, S. Historic mining and agriculture as indicators of occurrence and abundance of widespread invasive plant species. PLoS ONE 2015, 10, e0128161. [CrossRef] [PubMed]

10. Corbett, E.; Anderson, R.; Rodgers, C. Prairie revegetation of a strip mine in Illinois: Fifteen years after establishment. Restor. Ecol. 1996, 4, 346-354. [CrossRef]

11. Adibee, N.; Osanloo, M.; Rahmanpour, M. Adverse effects of coal mine waste dumps on the environment and their management. Environ. Earth Sci. 2013, 70, 1581-1592. [CrossRef]

12. Dhar, S.B.; Dutta, M. Changing land use pattern in the Raniganj Coal Belt and its sustainable management: A case study of Mangalpur Opencast Colliery. Curr. World Environ. 2020, 15, 76-88. [CrossRef]

13. Langkamp, P.J. Potential conflict between the coal and arable land resources in Australia: A case for corporate responsiveness. Environ. Manag. 1985, 9, 49-60. [CrossRef]

14. Oskarsson, P.; Lahiri-Dutt, K.; Wennström, P. From incremental dispossession to a cumulative land grab: Understanding territorial transformation in India's North Karanpura Coalfield. Dev. Change 2019, 50, 1485-1508. [CrossRef]

15. Brevik, E.C.; Sauer, T.J. The past, present, and future of soils and human health studies. Soil 2015, 1, 35-46. [CrossRef]

16. Phillips, H.A. Pollution of the atmosphere. Nature 1882, 27, 127. [CrossRef]

17. Sharma, A.; Sumbali, G. Ecobiology of coal mines and spoils. J. Appl. Nat. Sci. 2019, 11, 624-631. [CrossRef]

18. Simpson, G.B.; Jewitt, G.P.W. The development of the water-energy-food nexus as a framework for achieving resource security: A Review. Front. Environ. Sci. 2019, 7, 8. [CrossRef]

19. Katzur, J.; Haubold-Rosar, M. Amelioration and reforestation of sulfurous mine soils in Lusatia (Eastern Germany). Water Air Soil Pollut. 1996, 91, 17-32. [CrossRef]

20. Li, M.S. Ecological restoration of mineland with particular reference to the metalliferous mine wasteland in China: A review of research and practice. Sci. Total Environ. 2006, 357, 38-53. [CrossRef]

21. Truter, W.J.; Rethman, N.F.G.; Potgieter, C.E.; Kruger, R.A. Re-vegetation of cover soils and coal discard material ameliorated with Class F fly ash. In Proceedings of the Collected Abstracts, 2009 World of Coal Ash (WOCA) Conference, Lexington, KY, USA, 9-12 May 2011. Available online: http:/ / energy.caer.uky.edu/AshSymposium/Agenda09.asp (accessed on 30 June 2020).

22. Cowan, A.K.; Lodewijks, H.M.; Sekhohola, L.M.; Edeki, O.G. In situ bioremediation of South African coal discard dumps. In Proceedings of the Mine Closure 2016 11th International Conference on Mine Closure, Perth, Australia, 15-17 March 2016; Fourie, A.B., Tibbett, M., Eds.; Australian Centre for Geomechanics: Perth, Australia, 2016; pp. 501-509. [CrossRef]

23. Lima, A.T.; Mitchella, K.; O'Connella, D.W.; Verhoeven, J.; Van Cappellen, P. The legacy of surface mining: Remediation, restoration, reclamation and rehabilitation. Environ. Sci. Policy 2016, 66, 227-233. [CrossRef]

24. Kundu, N.K.; Ghose, M.K. Shelf life of stock-piled topsoil of an opencast coal mine. Environ. Conser. 1997, 24, 24-30. [CrossRef]

25. Glaser, B.; Lehmann, J.; Zech, W. Ameliorating physical and chemical properties of highly weathered soils in the tropics with charcoal-A review. Biol. Fert. Soils 2002, 35, 219-230. [CrossRef]

26. Stahl, P.D.; Williams, S.E.; Christensen, M. Efficacy of native vesicular-arbuscular mycorrhizal fungi after severe soil disturbance. New Phytol. 1988, 110, 347-354. [CrossRef]

27. Claassens, S.; Jansen Van Rensburg, P.J.; Van Rensburg, L. Soil microbial community structure of coal mine discard under rehabilitation. Water Air Soil Pollut. 2006, 174, 355-366. [CrossRef]

28. Claassens, S.; Riedel, K.J.; Van Rensburg, L.; Bezuidenhout, J.J.; Jansen van Rensburg, P.J. Microbial community function and structure on coal mine discard under rehabilitation. S. Afr. J. Plant Soil 2006, 23, 105-112. [CrossRef] 
29. Šourková, M.; Frouz, J.; Fettweis, U.; Bens, O.; Hüttl, R.; Šantrůčková, H. Soil development and properties of microbial biomass succession in reclaimed post mining sites near Sokolov (Czech Republic) and near Cottbus (Germany). Geoderma 2005, 129, 73-80. [CrossRef]

30. Igbinigie, E.E.; Aktins, S.; Van Breugel, Y.; Van Dyke, S.; Davies-Coleman, M.T.; Rose, P.D. Fungal biodegradation of hard coal by a newly reported isolate, Neosartorya fischeri. Biotechnol. J. 2008, 3, 1407-1416. [CrossRef]

31. Igbinigie, E.E.; Mutambanengwe, C.Z.; Rose, P.D. Phyto-bioconversion of hard coal in the Cyanodon dactylon/coal rhizosphere. Biotechnol. J. 2010, 5, 292-303. [CrossRef]

32. Mukasa-Mugerwa, T.T.; Dames, J.F.; Rose, P.D. The role of a plant/fungal consortium in the degradation of bituminous hard coal Biodegradation 2011, 22, 129-141. [CrossRef]

33. Sekhohola, L.M.; Isaacs, M.L.; Cowan, A.K. Fungal colonization and enzyme-mediated metabolism of waste coal by Neosartorya fischeri strain ECCN 84. Biosci. Biotechnol. Biochem. 2014, 78, 1797-1802. [CrossRef]

34. Sekhohola, L.M.; Cowan, A.K. Biological conversion of low-grade coal discard to a humic substance-enriched soil-like material. Int. J. Coal Sci. Technol. 2017, 4, 183-190. [CrossRef]

35. Rose, P.D.; Igbinigie, E.E.; Mukasa-Mugerwa, T.; Dames, J. Beneficiation of Coal. S. Afr. Patent No. RSA2010/023542010, 26 October 2011.

36. Lottermoser, B.G. Recycling, reuse and rehabilitation of mine wastes. Elements 2011, 7, 405-410. [CrossRef]

37. Zásterová, P.; Marschalkoa, M.; Niemieca, D.; Durćáka, J.; Bulkob, R.; Vlček, J. Analysis of possibilities of reclamation waste dumps after coal mining. Procedia Earth Planet. Sci. 2015, 15, 656-662. [CrossRef]

38. Nadudvari, A.A.; Kozielska, B.; Abramowicz, A.; Fabianska, M.; Ciesielczuk, J.; Cabała, J.; Krzykawski, T. Heavy metal- and organic-matter pollution due to self-heating coal-waste dumps in the Upper Silesian Coal Basin (Poland). J. Hazard. Mater. 2021, 412, 125244. [CrossRef] [PubMed]

39. Adhikari, K.; Mal, U. Evaluation of contamination of manganese in groundwater from overburden dumps of Lower Gondwana coal mines. Environ. Earth Sci. 2021, 80, 1-15. [CrossRef]

40. Cogho, V.E. Optimum Coal Mine: Striving towards a 'zero effluent' mine. J. S. Afr. Inst. Min. Metall. 2012, 112, 119-126.

41. Li, W.; Wang, D.; Li, H. Environmental engineering issues induced by abandoned coal mine hidden disasters. IOP Conf. Ser. Earth Environ. Sci. 2019, 237, 022039. [CrossRef]

42. Agboola, O.; Babatunde, D.E.; Fayomi, O.S.I.; Sadiku, E.R.; Popoola, P.; Moropeng, L.; Yahaya, A.; Mamudu, O.-A. A review on the impact of mining operation: Monitoring, assessment and management. Results Eng. 2020, 8, 100181. [CrossRef]

43. Cui, X.; Peng, S.; Lines, L.R.; Zhu, G.; Hu, Z.; Cui, F. Understanding the capability of an ecosystem nature-restoration in coal mined area. Sci. Rep. 2019, 9, 19690. [CrossRef]

44. Jawarkar, A.A.; Jambhulkar, H.P. Phytoremediation of coal mine spoil dump through integrated biotechnology approach Bioresour. Technol. 2008, 99, 4732-4741. [CrossRef]

45. Pierwoła, J.; Ciesielczuk, J.; Misz-Kennan, M.; Fabiańska, M.J.; Bielińska, A.; Kruszewski, Ł. Structure and thermal history of the Wełnowiec Dump, Poland: A municipal dump rehabilitated with coal waste. Int. J. Coal Geol. 2018, 197, 1-19. [CrossRef]

46. Ran, Z.; Pan, Y.; Liu, W. Co-disposal of coal gangue and red mud for prevention of acid mine drainage generation from self-heating gangue dumps. Minerals 2020, 10, 1081. [CrossRef]

47. Valero, N.; Melgarejo, L.M.; Ramírez, R. Effect of low-rank coal inoculated with coal solubilizing bacteria on edaphic materials used in post-coal-mining land reclamation: A greenhouse trial. Chem. Biol. Technol. Agric. 2016, 3, 20. [CrossRef]

48. Coppin, N.J. An ecologist in mining-A retrospective of 40 years in mine closure and reclamation. In Proceedings of the Eighth International Seminar on Mine Closure; Tibbett, M., Fourie, A.B., Digby, C., Eds.; Australian Centre for Geomechanics: Crawley, Australia, 2013; pp. 295-310.

49. Limpitlaw, D.; Briel, A. Post-mining land use opportunities in developing countries-A review. J. S. Afr. Inst. Min. Metall. 2015, $114,1-5$.

50. Unger, C.J.; Everingham, J.A.; Bond, C.J. Transition or transformation: Shifting priorities and stakeholders in Australian mined land rehabilitation and closure. Australas. J. Environ. Manag. 2020, 27, 84-113. [CrossRef]

51. Sekhohola, L.M.; Igbinigie, E.E.; Cowan, A.K. Biological degradation and solubilization of coal. Biodegradation 2013, 24, 305-318. [CrossRef]

52. Ghani, M.J.; Rajoka, M.; Akhtar, K. Investigations in fungal solubilization of coal: Mechanisms and significance. Biotechnol. Bioprocess Eng. 2015, 20, 634-642. [CrossRef]

53. Reich-Walber, M.; Meyrahn, H.; Lenz, U. Rheinbraun's concept for power generation based on biotechnologically converted lignite. Fuel Process. Technol. 1997, 52, 267-277. [CrossRef]

54. Hölker, U.; Mönkemann, H.; Höfer, M. A system to analyze the complex physiological states of coal solubilizing fungi. Fuel Process. Technol. 1997, 52, 65-71. [CrossRef]

55. Mönkemann, H.; Hölker, U.; Höfer, M. Components of the ligninolytic system of Fusarium oxysporum and Trichoderma atroviride. Fuel Process. Technol. 1997, 52, 73-77. [CrossRef]

56. Ralph, J.P.; Catcheside, D.E.A. Transformations of low rank coal by Phanerochaete chrysosporium and other wood-rot fungi. Fuel Process. Technol. 1997, 52, 79-93. [CrossRef]

57. Fakoussa, R.; Frost, P. In vivo-decolorization of coal-derived humic acids by laccase-excreting fungus Trametes versicolor. Appl. Microbiol. Biotechnol. 1999, 52, 60-65. [CrossRef] 
58. Kwiatos, N.; Jędrzejczak-Krzepkowska, M.; Strzelecki, B.; Bielecki, S. Improvement of efficiency of brown coal biosolubilization by novel recombinant Fusarium oxysporum laccase. AMB Express 2018, 8, 133. [CrossRef] [PubMed]

59. Kwiatos, N.; Jędrzejczak-Krzepkowska, M.; Krzemińska, A.; Delavari, A.; Paneth, P.; Bielecki, S. Evolved Fusarium oxysporum laccase expressed in Saccharomyces cerevisiae. Sci. Rep. 2020, 10, 3244. [CrossRef] [PubMed]

60. Crawford, D.L.; Gupta, R.K. Characterization of extracellular bacterial enzymes which depolymerize a soluble lignite coal polymer. Fuel 1991, 70, 577-580. [CrossRef]

61. Campbell, J.A.; Stewart, D.L.; McCulloch, M.; Lucke, R.B.; Bean, R.M. Biodegradation of coal-related model compounds. Am. Chem. Soc. Div. Fuel Chem. Prep. 1988, 33, 514.

62. Hölker, U.; Schmiers, H.; Große, S.; Winkelhöfer, M.; Polsakiewicz, M.; Ludwig, S.; Dohse, J.; Höfer, M. Solubilization of low-rank coal by Trichoderma atroviride: Evidence for the involvement of hydrolytic and oxidative enzymes by using ${ }^{14} \mathrm{C}$-labelled lignite. J. Ind. Microbiol. Biotechnol. 2002, 28, 207-212. [CrossRef] [PubMed]

63. Yuan, H.L.; Yang, J.S.; Chen, W.X. Production of alkaline materials, surfactants and enzymes by Penicillium decumbens strain P6 in association with lignite degradation/solubilization. Fuel 2006, 85, 1378-1382. [CrossRef]

64. Yang, Y.; Yang, J.; Li, B.; Wang, E.; Yuan, H. An esterase from Penicillium decumbens P6 involved in lignite depolymerization. Fuel 2018, 214, 416-422. [CrossRef]

65. Sudheer, P.D.V.N.; David, Y.; Chae, C.G.; Kim, Y.J.; Baylon, M.G.; Baritugo, K.-A.; Kim, T.W.; Kim, M.-S.; Na, J.G.; Park, S.J Advances in the biological treatment of coal for synthetic natural gas and chemicals. Korean J. Chem. Eng. 2016, 33, 2788-2801. [CrossRef]

66. Olawale, J.T.; Edeki, O.G.; Cowan, A.K. Bacterial degradation of coal discard and geologically weathered coal. Int. J. Coal Sci. Technol. 2020, 7, 405-416. [CrossRef]

67. Ghani, M.J.; Akhtar, K.; Khaliq, S.; Akhtar, N.; Ghauri, M.A. Characterization of humic acids produced from fungal liquefaction of low-grade Thar coal. Process Biochem. 2021, 107, 1-12. [CrossRef]

68. Gupta, R. Advanced coal characterization: A review. Energy Fuels 2007, 21, 451-460. [CrossRef]

69. Ulrich, G.; Bower, S. Active methanogenesis and acetate utilization in Powder River Basin coals. United States. Int. J. Coal Geol. 2008, 76, 25-33. [CrossRef]

70. Lozano, C.J.S.; Mendoza, M.V.; de Arango, M.C.; Monroy, E.F.C. Microbiological characterization and specific methanogenic activity of anaerobe sludges used in urban solid waste treatment. Waste Manag. 2009, 29, 704-711. [CrossRef] [PubMed]

71. Sharma, A.; Jani, K.; Thite, V.; Dhar, S.K.; Shouche, Y. Geochemistry shapes bacterial communities and their metabolic potentials in tertiary coalbed. Geomicrobiol. J. 2019, 36, 179-187. [CrossRef]

72. Zhubanova, A.A.; Xiaohui, Q.; Ualieva, P.S.; Abdieva, G.Z.; Tastambek, K.T.; Kayrmanova, G.K.; Akimbekov, N.S. Metagenomic analysis reveals correlation between microbiome structure and Leonardite characteristics from Kazakhstan coal deposits. Eurasian Chem.-Technol. J. 2019, 21, 135-141. [CrossRef]

73. Green, M.S.; Flanegan, K.C.; Gilcrease, P.C. Characterization of a methanogenic consortium enriched from a coalbed methane well in the Powder River Basin, U.S.A. Int. J. Coal Geol. 2008, 76, 34-45. [CrossRef]

74. Harris, S.H.; Smith, R.L.; Barker, C.E. Microbial and chemical factors influencing methane production in laboratory incubations of low-rank subsurface coals. Int. J. Coal Geol. 2008, 76, 46-51. [CrossRef]

75. Johnson, E.R.; Klasson, K.T.; Basu, R.; Volkwein, J.C.; Clausen, E.C.; Gaddy, J.L. Microbial conversion of high-rank coals to methane. Appl. Biochem. Biotechnol. 1994, 45-46, 329-338. [CrossRef]

76. Volkwein, J.C.; Schoeneman, A.L.; Clausen, E.G.; Gaddy, J.L.; Johnson, E.R.; Basu, R.; Ju, N.; Klasson, K.T. Biological production of methane from bituminous coal. Fuel Process Technol. 1994, 40, 339-345. [CrossRef]

77. Budwill, K. Microbial methanogenesis and its role in enhancing coalbed methane recovery. In CSEG Recorder; Alberta Research Council: Edmonton, AB, Canada, 2003.

78. Jones, E.J.P.; Voytek, M.A.; Warwick, P.D.; Corum, M.D.; Cohn, A.; Bunnell, J.E.; Clark, A.C.; Orem, W.H. Bioassay for estimating the biogenic methane-generating potential of coal samples. Int. J. Coal Geol. 2008, 76, 138-150. [CrossRef]

79. Panow, A.; FitzGerald, J.M.P.; Mainwaring, D.E. Mechanisms of biologically-mediated methane evolution from black coal. Fuel Process. Technol. 1997, 52, 115-125. [CrossRef]

80. Pérez, M.; Romero, L.I.; Nebot, E.; Sales, D. Colonisation of a porous sintered-glass support in anaerobic thermophilic bioreactors Bioresour. Technol. 1997, 59, 177-183. [CrossRef]

81. Gupta, A.; Birendra, K. Biogasification of coal using different sources of microorganisms. Fuel 2000, 79, 103-105. [CrossRef]

82. Chang, B.V.; Chang, S.W.; Yuan, S.Y. Anaerobic degradation of polycyclic aromatic hydrocarbons in sludge. Adv. Environ. Res. 2003, 7, 623-628. [CrossRef]

83. Hazrin-Chong, N.H.; Marjo, C.E.; Das, T.; Rich, A.M.; Manefield, M. Surface analysis reveals biogenic oxidation of sub-bituminous coal by Pseudomonas fluorescens. Appl. Microbiol. Biotechnol. 2014, 98, 6443-6452. [CrossRef] [PubMed]

84. Levania, M.; Cheema, S.; Sarma, P.M.; Ganapathi, R. Methanogenic potential of a thermophilic consortium enriched from coal mine. Int. Biodeterior. Biodegrad. 2014, 93, 177-185. [CrossRef]

85. Valero, N.; Gómez, L.; Pantoja, M.; Ramirez, R. Production of humic substances through coal solubilizing bacteria. Braz. J. Microbiol. 2014, 45, 911-918. [CrossRef]

86. Romanowska, I.; Strzelecki, B.; Bielecki, S. Biosolubilization of Polish brown coal by Gordonia alkanivorans S7 and Bacillus mycoides NS1020. Fuel Process. Technol. 2015, 131, 430-436. [CrossRef] 
87. Wang, B.; Wang, Y.; Cui, X.; Zhang, Y.; Yu, Z. Bioconversion of coal to methane by microbial communities from soil and from an opencast mine in the Xilingol grassland of northeast China. Biotechnol. Biofuels 2019, 12, 236. [CrossRef]

88. Opara, A.; Adams, D.; Free, M.L.; McLennan, J.; Hamilton, J. Microbial production of methane and carbon dioxide from lignite, bituminous coal, and coal waste materials. Int. J. Coal Geol. 2012, 96-97, 1-8. [CrossRef]

89. Zhang, J.; Liang, Y.; Pandey, R.; Harpalani, S. Characterizing microbial communities dedicated for conversion of coal to methane in-situ and ex-situ. Int. J. Coal Geol. 2015, 146, 145-154. [CrossRef]

90. He, H.; Han, Y.; Jin, D.; Leng, Y.; Sun, Q.; Shen, L.; Tao, X. Microbial consortium in a non-production biogas coal mine of eastern China and its methane generation from lignite. Energy Source Part A 2016, 38, 1377-1384. [CrossRef]

91. Mayumi, D.; Mochimaru, H.; Tamaki, H.; Yamamoto, K.; Yoshioka, H.; Suzuki, Y.; Kamagata, Y.; Sakata, S. Methane production from coal by a single methanogen. Science 2016, 354, 222-225. [CrossRef] [PubMed]

92. Guo, H.; Zhao, S.; Xia, D.; Wang, L.; Lv, J.; Yu, H.; Jiao, X. Efficient utilization of coal slime using anaerobic fermentation technology. Bioresour. Technol. 2021, 332, 125072. [CrossRef]

93. O'Keefe, J.M.K.; Bechtel, A.; Christanis, K.; Dai, S.; DiMichele, W.A.; Eblef, C.F.; Esterle, J.S.; Mastalerz, M.; Raymond, A.L.; Valentim, B.V.; et al. On the fundamental difference between coal rank and coal type. Int. J. Coal Geol. 2013, 118, 58-87. [CrossRef]

94. Giannouli, A.; Stavros, K.; Siavalas, G.; Chatziapostolou, A.; Christanis, K.; Papazisimou, S.; Papanicolaou, C.; Foscolos, A. Evaluation of Greek low-rank coals as potential raw material for the production of soil amendments and organic fertilizers. Int. J. Coal Geol. 2009, 477, 383-393. [CrossRef]

95. Van de Venter, H.A.; Furter, M.; Dekker, J.; Cronje, I.J. Stimulation of seedling root growth by coal-derived sodium humate. Plant Soil 1991, 138, 17-21. [CrossRef]

96. Janoš, P. Separation methods in the chemistry of humic substances. J. Chromatog. A 2003, 983, 1-18. [CrossRef]

97. Zhou, L.; Yuan, L.; Zhao, B.; Li, Y.; Lin, Z. Structural characteristics of humic acids derived from Chinese weathered coal under different oxidizing conditions. PLoS ONE 2019, 14, e0217469. [CrossRef]

98. Cheng, G.; Niu, Z.; Zhang, C.; Zhang, X.; Li, X. Extraction of humic acid from lignites by KOH-hydrothermal method. Appl. Sci. 2019, 9, 1356. [CrossRef]

99. Yildirim, M.; Özbayoğlu, G. Production of ammonium nitrohumate from Elbistan lignite and its use as a coal binder. Fuel 1997, 76, 385-389. [CrossRef]

100. Kurniati, E.; Muljani, S.; Virgani, D.G.; Neno, B.P. Humic acid isolations from lignite by ion exchange method. J. Phys. Conf. Ser. 2018, 953, 012234. [CrossRef]

101. Doskočil, L.; Grasset, L.; Válková, D.; Pekar, M. Hydrogen peroxide oxidation of humic acids and lignite. Fuel 2014, 134, 406-413. [CrossRef]

102. Chen, H.; Kim, H.U.; Weng, H.; Browse, J. Malonyl-CoA synthetase, encoded by ACYL ACTIVATING ENZYME13, is essential for growth and development of Arabidopsis. Plant Cell 2011, 23, 2247-2262. [CrossRef]

103. Hofrichter, M.; Fakoussa, R.M. Microbial degradation and modification of coal. In Lignin, Humic Substances and Coal; Steinbüchel, A., Ed.; Wiley-VCH: Weinheim, Germany, 2004; pp. 399-425.

104. David, Y.; Baylon, M.G.; Pamidimarri, S.D.V.N.; Baritugo, K.-A.; Chae, C.G.; Kim, Y.J.; Kim, T.W.; Kim, M.-S.; Na, J.G.; Park, S.J. Screening of microorganisms able to degrade low-rank coal in aerobic conditions: Potential coal biosolubilization mediators from coal to biochemicals. Biotechnol. Bioprocess Eng. 2017, 22, 178-185. [CrossRef]

105. Akimbekov, N.; Digel, I.; Abdieva, G.; Ualieva, P.; Tastambek, K. Lignite biosolubilization and bioconversion by Bacillus sp.: The collation of analytical data. Biofuels 2021, 12, 247-258. [CrossRef]

106. Akimbekov, N.; Digel, I.; Qiaoa, X.; Tastambeka, K.; Zhubanova, A. Lignite biosolubilization by Bacillus sp. RKB 2 and characterization of its products. Geomicrobiol. J. 2020, 37, 255-261. [CrossRef]

107. Titilawo, Y.; Masudi, W.L.; Olawale, J.T.; Sekhohola-Dlamini, L.M.; Cowan, A.K. Coal-degrading bacteria display characteristics typical of plant growth promoting rhizobacteria. Processes 2020, 8, 1111. [CrossRef]

108. Kluláková, M.; Pavlíková, M. Lignitic humic acids as environmentally-friendly adsorbent for heavy metals. J. Chem. 2017, 2017, 7169019. [CrossRef]

109. De Souza, F.; Braganc, S.R. Extraction and characterization of humic acid from coal for the application as dispersant of ceramic powders. J. Mater. Res. Technol. 2018, 7, 254-260. [CrossRef]

110. Akimbekov, N.; Qiao, X.; Digel, I.; Abdieva, G.; Ualieva, P.; Zhubanova, A. The Effect of Leonardite-derived amendments on soil microbiome structure and potato yield. Agriculture 2020, 10, 147. [CrossRef]

111. Gong, G.; Xu, L.; Zhang, Y.; Liu, W.; Wang, M.; Zhao, Y.; Yuan, X.; Li, Y. Extraction of fulvic acid from lignite and characterization of its functional groups. ACS Omega 2020, 5, 27953-27961. [CrossRef] [PubMed]

112. Jeong, H.J.; Oh, M.S.; Rehman, J.U.; Yoon, H.Y.; Kim, J.-H.; Shin, J.; Shin, S.G.; Bae, H.; Jeon, J.-R. Effects of microbes from coal-related commercial humic substances on hydroponic crop cultivation: A microbiological view for agronomical use of humic substances. J. Agric. Food Chem. 2021, 69, 805-814. [CrossRef]

113. Yang, F.; Du, Q.; Sui, L.; Cheng, K. One-step fabrication of artificial humic acid-functionalized colloid-like magnetic biochar for rapid heavy metal removal. Bioresour. Technol. 2021, 328, 124825. [CrossRef]

114. Wang, C.-F.; Fan, X.; Zhang, F.; Wang, S.-Z.; Zhao, Y.-P.; Zhao, X.-Y.; Zhao, W.; Zhu, T.-G.; Lu, J.-L.; Wei, X.-Y. Characterization of humic acids extracted from a lignite and interpretation for the mass spectra. RSC Adv. 2017, 7, 20677. [CrossRef] 
115. Perminova, I.V. From green chemistry and nature-like technologies towards ecoadaptive chemistry and technology. Pure Appl. Chem. 2019, 91, 851-864. [CrossRef]

116. Bankowski, P.; Zou, L.; Hodges, R. A case study on stabilization and reuse of geopolymer-encapsulated brown coal fly ash. Int. J. Sus. Dev. Plann. 2006, 1, 76-90. [CrossRef]

117. Mucsi, G.; Molnár, Z.; Kumar, S. Geopolymerisation of mechanically activated lignite and brown coal fly ash. Acta Phys. Pol. A 2014, 126, 994-998. [CrossRef]

118. Yi, C.; Ma, H.; Chen, H.; Wang, J.; Shi, J.; Li, Z.; Yu, M. Preparation and characterization of coal gangue geopolymers. Constr. Build. Mater. 2018, 187, 318-326. [CrossRef]

119. Lipczynska-Kochany, E. Humic substances, their microbial interactions and effects on biological transformations of organic pollutants in water and soil: A review. Chemosphere 2018, 202, 420-437. [CrossRef] [PubMed]

120. Sachkova, A.S.; Kovel, E.S.; Churilov, G.N.; Stom, D.I.; Kudryasheva, N.S. Biological activity of carbonic nano-structurescomparison via enzymatic bioassay. J. Soils Sediments 2019, 19, 2689-2696. [CrossRef]

121. Sondreal, E.A.; Wiltsee, G.A. Low-rank coal: Its present and future role in the United States. Annu. Rev. Energy 1984, 9, 473-479. [CrossRef]

122. American Society for Testing and Materials. Annual Book of ASTM Standards, Section 5, Petroleum Products, Lubricants, and Fossil Fuels, v. 05.05, Gaseous Fuels; Coal and Coke; American Society for Testing and Materials: Philadelphia, PA, USA, 1999; pp. 155-584.

123. Mochida, I.; Okuma, O.; Yoon, S.H. Chemicals from direct coal liquefaction. Chem. Rev. 2014, 114, 1637-1672. [CrossRef]

124. Haider, K.; Martin, J.P. Synthesis and transformation of phenolic compounds by Epicoccum nigrum in relation to humic acid formation. Soil Sci. Soc. Am. J. 1967, 31, 766-772. [CrossRef]

125. Crawford, D.L.; Gupta, R.K. Influence of cultural parameters on the depolymerization of a soluble lignite coal polymer by Pseudomonas cepacia DLC-071. Resour. Conserv. Recycl. 1991, 5, 245-254. [CrossRef]

126. Macheroux, P.; Schmid, J.; Amrhein, N.; Schaller, A. A unique reaction in a common pathway: Mechanism and function of chorismate synthase in the shikimate pathway. Planta 1999, 207, 325-334. [CrossRef] [PubMed]

127. Gerke, J. Concepts and misconceptions of humic substances as the stable part of soil organic matter: A review. Agronomy 2018, 8, 76. [CrossRef]

128. Hänninen, K. Historical and current progress in understanding the origin and structure of humic substances. Chem. Ecol. 2010, 26, 1-11. [CrossRef]

129. Misztal, P.K.; Hewitt, C.N.; Wildt, J.; Blande, J.D.; Eller, A.S.D.; Fares, S.; Gentner, D.R.; Gilman, J.B.; Graus, M.; Greenberg, J.; et al. Atmospheric benzenoid emissions from plants rival those from fossil fuels. Sci. Rep. 2015, 5, 12064. [CrossRef]

130. Dakora, F.D.; Phillips, D.A. Root exudates as mediators of mineral acquisition in low-nutrient environments. Plant Soil 2002, 245, 35-47. [CrossRef]

131. Jin, C.W.; You, G.Y.; He, Y.F.; Tang, C.; Wu, P.; Zheng, S.J. Iron deficiency-induced secretion of phenolics facilitates the reutilization of root apoplastic iron in red clover. Plant Physiol. 2007, 144, 278-285. [CrossRef] [PubMed]

132. Zwetsloot, M.J.; Kessler, A.; Bauerle, T.L. Phenolic root exudate and tissue compounds vary widely among temperate forest tree species and have contrasting effects on soil microbial respiration. New Phytol. 2018, 218, 530-541. [CrossRef] [PubMed]

133. Zwetsloot, M.J.; Ucros, J.M.; Wickings, K.; Wilhelm, R.C.; Sparks, J.; Buckley, D.H.; Bauerle, T.L. Prevalent root-derived phenolics drive shifts in microbial community composition and prime decomposition in forest soil. Soil Biol. Biochem. 2020, 145, 107797. [CrossRef]

134. Wu, D.; Wei, Z.M.; Qu, F.T.; Mohamed, T.A.; Zhu, L.J.; Zhao, Y.; Jia, L.M.; Zhao, R.; Liu, L.J.; Li, P. Effect of Fenton pretreatment combined with bacteria inoculation on humic substances formation during lignocellulosic biomass composting derived from rice straw. Bioresour. Technol. 2020, 303, 122849. [CrossRef]

135. Wu, D.; Xia, T.; Zhang, Y.; Wei, Z.; Qu, F.; Zheng, G.; Song, C.; Zhao, Y.; Kang, K.; Yang, H. Identifying driving factors of humic acid formation during rice straw composting based on Fenton pretreatment with bacterial inoculation. Bioresour. Technol. 2021, 337, 125403. [CrossRef]

136. Ye, Z.; Ding, H.; Yin, Z.; Ping, W.; Ge, J. Evaluation of humic acid conversion during composting under amoxicillin stress: Emphasizes the driving role of core microbial communities. Bioresour. Technol. 2021, 337, 125483. [CrossRef]

137. Pollegioni, L.; Tonin, F.; Rosini, E. Lignin-degrading enzymes. FEBS J. 2015, 282, 1190-1213. [CrossRef] [PubMed]

138. Meng, Q.; Wang, S.; Niu, Q.; Yan, H.; Li, G.; Zhu, Q.; Li, Q. Illite/smectite clay regulating laccase encoded genes to boost lignin decomposition and humus formation in composting habitats revealed by metagenomics analysis. Bioresour. Technol. 2021, 338, 125546. [CrossRef]

139. Li, F.; Zhao, H.; Shao, R.; Zhang, X.; Yu, H. Enhanced Fenton reaction for xenobiotic compounds and lignin degradation fueled by quinone redox cycling by lytic polysaccharide monooxygenases. J. Agric. Food Chem. 2021, 69, 7104-7114. [CrossRef]

140. Grinhut, T.; Hadar, Y.; Chen, Y. Degradation and transformation of humic substances by saprotrophic fungi: Processes and mechanisms. Fungal Biol. Rev. 2007, 21, 179-189. [CrossRef]

141. Qi, H.; Zhai, W.; Du, Y.; Zhao, Y.; Wei, Z.; Wu, J.; Xie, X.; Yang, H.; Wu, D.; Guo, T. Core bacterial community driven conversion of fulvic acid components during composting with adding manganese dioxide. Bioresour. Technol. 2021, 337, 125495. [CrossRef] [PubMed] 
142. Kallenbach, C.M.; Frey, S.D.; Grandy, A.S. Direct evidence for microbial-derived soil organic matter formation and its ecophysiological controls. Nat. Commun. 2016, 7, 13630. [CrossRef] [PubMed]

143. Baveye, P.C.; Wander, M. The (bio)chemistry of soil humus and humic substances: Why is the "new view" still considered novel after more than 80 years? Front. Environ. Sci. 2019, 7, 27. [CrossRef]

144. Waksman, S.A. Humus. Origin, Chemical Composition, and Importance in Nature; The Williams \& Wilkins Company: Baltimore, MD, USA, 1936; pp. 1-508.

145. Salt, D.E.; Smith, R.D.; Raskin, I. Phytoremediation. Annu. Rev. Plant Physiol. Plant Mol. Biol. 1998, 49, 643-668. [CrossRef]

146. Pilon-Smits, E. Phytoremediation. Annu. Rev. Plant Biol. 2005, 56, 15-39. [CrossRef]

147. Masciandaro, G.; Macci, C.; Ceccanti, B.; Doni, S. Organic matter-microorganism-plant in soil bioremediation: A synergic approach. Rev. Environ. Sci. Biotechnol. 2013, 12, 399419. [CrossRef]

148. Kurade, M.B.; Ha, Y.-H.; Xiong, J.-Q.; Govindwar, S.P.; Jang, M.; Jeon, B.-H. Phytoremediation as a green biotechnology tool for emerging environmental pollution: A step forward towards sustainable rehabilitation of the environment. Chem. Eng. J. 2021, 415, 129040. [CrossRef]

149. Wei, Z.; Van Le, Q.; Peng, W.; Yang, Y.; Yang, H.; Gu, H.; Lam, S.S.; Sonne, C. A review on phytoremediation of contaminants in air, water and soil. J. Hazard. Mater. 2021, 403, 123658. [CrossRef] [PubMed]

150. Upcraft, T.; Guo, M. Phytoremediation value chains and modeling. In Sustainable Remediation of Contaminated Soil and Groundwater: Materials, Processes, and Assessment, 1st ed.; Hou, D., Ed.; Elsevier: Oxford, UK, 2020; pp. 325-366. [CrossRef]

151. Naylor, D.; Sadler, N.; Bhattacharjee, A.; Graham, E.B.; Anderton, C.R.; McClure, R.; Lipton, M.; Hofmockel, K.S.; Jansson, J.K. Soil microbiomes under climate change and implications for carbon cycling. Annu. Rev. Environ. Resour. 2020, 45, 29-59. [CrossRef]

152. Jansson, J.K.; Hofmockel, K.S. The soil microbiome-From metagenomics to metaphenomics. Curr. Opin. Microbiol. 2018, 43, 162-168. [CrossRef] [PubMed]

153. Wenzel, W.W. Rhizosphere processes and management in plant-assist bioremediation (phytoremediation) of soils. Plant Soil 2009, 321, 385-408. [CrossRef]

154. Brundrett, M.C. Coevolution of roots and mycorrhizas of land plants. New Phytol. 2002, 154, 275-304. [CrossRef] [PubMed]

155. Vives-Peris, V.; de Ollas, C.; Gómez-Cadenas, A.; Pérez-Clemente, R.M. Root exudates: From plant to rhizosphere and beyond. Plant Cell Rep. 2020, 39, 3-17. [CrossRef]

156. Zhang, J.; Zhou, J.-M. Plant immunity triggered by microbial molecular signatures. Mol. Plant 2010, 3, 783-793. [CrossRef]

157. Pérez-de-Luque, A.; Tille, S.; Johnson, I.; Pascual-Pardo, D.; Ton, J.; Cameron, D.D. The interactive effects of arbuscular mycorrhiza and plant growth-promoting rhizobacteria synergistically enhance host plant defences against pathogens. Sci. Rep. 2017, 7, 16409. [CrossRef]

158. Piccolo, A. The supramolecular structure of humic substances. Soil Sci. 2001, 166, 810-832. [CrossRef]

159. Simpson, A.J.; Kingery, W.L.; Hayes, M.H.; Spraul, M.; Humpfer, E.; Dvortsak, P.; Kerssebaum, R.; Hofmann, M. Molecular structures and associations of humic substances in the terrestrial environment. Naturwissenschaften 2002, 89, 84-88. [CrossRef]

160. Sutton, R.; Sposito, G. Molecular structure in soil humic substances: The new view. Environ. Sci. Technol. 2005, 39, 9009-9015. [CrossRef]

161. Piccolo, A.; Nardi, S.; Concheri, G. Macromolecular changes of humic substances induced by interaction with organic acids. Eur. J. Soil Sci. 1996, 47, 319-328. [CrossRef]

162. Piccolo, A.; Nardi, S.; Concheri, G. Micelle-like conformation of humic substances as revealed by size exclusion chromatography. Chemosphere 1996, 33, 595-602. [CrossRef]

163. Nardi, S.; Reniero, F.; Concheri, G. Soil organic matter mobilization by root exudates of three maize hybrids. Chemosphere 1997, 35, 2237-2244. [CrossRef]

164. Lehtonen, K.; Hänninen, K.; Ketola, M. Structurally bound lipids in peat humic acids. Org. Geochem. 2001, 32, 33-43. [CrossRef]

165. Trubetskoj, O.A.; Richard, C.; Guyot, G.; Voyard, G.; Trubetskaya, O.E. Analysis of electrophoretic soil humic acids fractions by reversed-phase high performance liquid chromatography with on-line absorbance and fluorescence detection. J. Chromatog. A 2012, 1243, 62-68. [CrossRef]

166. Trubetskoi, O.A.; Trubetskaya, O.E. Reversed-phase high-performance liquid chromatography of the stable electrophoretic fractions of soil humic acids. Eurasia Soil Sci. 2015, 48, 148-156. [CrossRef]

167. Wershaw, R.L. A new model for humic materials and their interactions with hydrophobic organic chemicals in soil-water and sediment-water systems. J. Contam. Hydrol. 1986, 1, 29-45. [CrossRef]

168. Semenov, V.M.; Tulina, A.S.; Semenova, N.A.; Ivannikova, L.A. Humification and nonhumification pathways of the organic matter stabilization in soil: A review. Eurasian Soil Sci. 2013, 46, 355-368. [CrossRef]

169. Badri, D.V.; Vivanco, J.M. Regulation and function of root exudates. Plant Cell. Environ. 2009, 32, 666-681. [CrossRef]

170. Jones, D.L.; Nguyen, C.; Finlay, R.D. Carbon flow in the rhizosphere: Carbon trading at the soil-root interface. Plant Soil 2009, 321, 5-33. [CrossRef]

171. Canarini, A.; Kaiser, C.; Merchant, A.; Richter, A.; Wanek, W. Root exudation of primary metabolites: Mechanisms and their roles in plant responses to environmental stimuli. Front. Plant Sci. 2019, 10, 157. [CrossRef]

172. Ivanov, S.; Austin, J.; Berg, R.H.; Harrison, M.J. Extensive membrane systems at the host-arbuscular mycorrhizal fungus interface. Nat. Plants 2019, 5, 194-203. [CrossRef] [PubMed] 
173. Roth, R.; Hillmer, S.; Funaya, C.; Chiapello, M.; Schumacher, K.; Lo Presti, L.; Regine Kahmann, R.; Paszkowski, U. Arbuscular cell invasion coincides with extracellular vesicles and membrane tubules. Nat. Plants 2019, 5, 204-211. [CrossRef] [PubMed]

174. De Palma, M.; Ambrosone, A.; Leone, A.; Del Gaudio, P.; Ruocco, M.; Turiák, L.; Bokka, R.; Fiume, I.; Tucci, M.; Pocsfalvi, G. Plant roots release small extracellular vesicles with antifungal activity. Plants 2020, 9, 1777. [CrossRef]

175. Deatherage, B.L.; Cookson, B.T. Membrane vesicle release in bacteria, eukaryotes, and archaea: A conserved yet underappreciated aspect of microbial life. Infect. Immun. 2012, 80, 1948-1957. [CrossRef]

176. Cui, Y.; Gao, J.; He, Y.; Jiang, L. Plant extracellular vesicles. Protoplasma 2020, 257, 3-12. [CrossRef]

177. Panepinto, J.; Komperda, K.; Frases, S.; Park, Y.-D.; Djordjevic, J.T.; Casadevall, A.; Williamson, P.R. Sec6-dependent sorting of fungal extracellular exosomes and laccase of Cryptococcus neoformans. Mol. Microbiol. 2009, 71, 1165-1176. [CrossRef]

178. Da Silva, R.P.; Puccia, R.; Rodrigues, M.L.; Oliveira, D.L.; Joffe, L.S.; César, G.V.; Nimrichter, L.; Goldenberg, S.; Alves, L.R. Extracellular vesicle-mediated export of fungal RNA. Sci. Rep. 2015, 5, 7763. [CrossRef]

179. Samuel, M.; Bleackley, M.; Anderson, M.; Mathivanan, S. Extracellular vesicles including exosomes in cross kingdom regulation: A viewpoint from plant-fungal interactions. Front. Plant Sci. 2015, 6, 766. [CrossRef]

180. Herkert, P.F.; Amatuzzi, R.F.; Alves, L.R.; Rodrigues, M.L. Extracellular vesicles as vehicles for the delivery of biologically active fungal molecules. Curr. Protein Pept. Sci. 2019, 20, 1027-1036. [CrossRef]

181. Rizzo, J.; Rodrigues, M.L.; Janbon, G. Extracellular vesicles in fungi: Past, Present, and future perspectives. Front. Cell Infect. Microbiol. 2020, 10, 346. [CrossRef]

182. Sakiyama, T.; Ueno, H.; Homma, H.; Numata, O.; Kuwabara, T. Purification and characterization of a hemolysin-like protein, Sll1951, a nontoxic member of the rtx protein family from the cyanobacterium Synechocystis sp. strain PCC 6803. J. Bacteriol. 2006, 188, 3535-3542. [CrossRef]

183. Joffe, L.S.; Nimrichter, L.; Rodrigues, M.L.; Del Poeta, M. Potential roles of fungal extracellular vesicles during infection. $m S p h e r e$ 2016, 1, e00099-16. [CrossRef]

184. Albuquerque, P.C.; Nakayasu, E.S.; Rodrigues, M.L.; Frases, S.; Casadevall, A.; Zancope-Oliveira, R.M.; Almeida, I.C.; Nosanchuk, J.D. Vesicular transport in Histoplasma capsulatum: An effective mechanism for trans-cell wall transfer of proteins and lipids in ascomycetes. Cell Microbiol. 2008, 10, 1695-1710. [CrossRef]

185. Deng, Z.; Rong, Y.; Teng, Y.; Mu, J.; Zhuang, X.; Tseng, M.; Samykutty, A.; Zhang, L.; Yan, J.; Miller, D.; et al. Broccoli-derived nanoparticle inhibits mouse colitis by activating dendritic cell AMP-activated protein kinase. Mol. Ther. 2017, 25, 1641-1654 [CrossRef] [PubMed]

186. Liu, G.; Kang, G.; Wang, S.; Huang, Y.; Cai, Q. Extracellular vesicles: Emerging players in plant defense against pathogens. Front. Plant Sci. 2021, 12, 757925. [CrossRef] [PubMed]

187. Regente, M.; Pinedo, M.; San Clemente, H.; Balliau, T.; Jamet, E.; de la Canal, L. Plant extracellular vesicles are incorporated by a fungal pathogen and inhibit its growth. J. Exp. Bot. 2017, 68, 5485-5495. [CrossRef] [PubMed]

188. Hansen, L.L.; Nielsen, M.A. Plant exosomes: Using an unconventional exit to prevent pathogen entry? J. Exp. Bot. 2018, 69, 59-68. [CrossRef] [PubMed]

189. Meldolesi, J. Exosomes and ectosomes in intercellular communication. Curr. Biol. 2018, 28, R435-R444. [CrossRef]

190. Teng, Y.; Ren, Y.; Sayed, M.; Hu, X.; Lei, C.; Kumar, A.; Hutchins, E.; Mu, J.; Deng, Z.; Luo, C.; et al. Plant-derived exosomal microRNAs shape the gut microbiota. Cell Host Microbe 2018, 24, 637-652.e8. [CrossRef]

191. Combarnous, Y.; Nguyen, T.M.D. Cell communications among microorganisms, plants, and animals: Origin, evolution, and interplays. Int. J. Mol. Sci. 2020, 21, 8052. [CrossRef]

192. Vincent, D.; Rafiqi, M.; Job, D. The multiple facets of plant-fungal interactions revealed through plant and fungal secretomics. Front. Plant Sci. 2020, 10, 1626. [CrossRef] [PubMed]

193. Gill, S.; Catchpole, R.; Forterre, P. Extracellular membrane vesicles in the three domains of life and beyond. FEMS Microbiol. Rev. 2019, 43, 273-303. [CrossRef] [PubMed]

194. Canellas, L.P.; Olivares, F.L. Physiological responses to humic substances as plant growth promoter. Chem. Biol. Technol. Agric. 2014, 1, 3. [CrossRef]

195. Susic, M. Replenishing humic acids in agricultural soils. Agronomy 2016, 6, 45. [CrossRef]

196. Wershaw, R.L. Evaluation of conceptual models of natural organic matter (humus) from a consideration of the chemical and biochemical processes of humification. US Geol. Surv. Sci. Investig. Rep. 2004, 5121, 44. Available online: http://pubs.usgs.gov/ sir/2004/5121/pdf/sir2004-5121.pdf (accessed on 29 April 2021).

197. Lehmann, J.; Kleber, M. The contentious nature of soil organic matter. Nature 2015, 528, 61-68. [CrossRef]

198. Tipping, E. WHAMC - A chemical equilibrium model and computer code for waters, sediments, and soils incorporating a discrete site/electrostatic model of ion-binding by humic substances. Comput. Geosci. 1994, 20, 973-1023. [CrossRef]

199. Nardi, S.; Concheri, G.; Pizzeghello, D.; Sturaro, A.; Rella, R.; Parvoli, G. Soil organic matter mobilization by root exudates. Chemosphere 2000, 41, 653-658. [CrossRef]

200. Piccolo, A. Special issue on: Humic molecules in soils. J. Geochem. Explor. 2013, 129, vii. [CrossRef]

201. Puglisi, E.; Fragoulis, G.; Ricciuti, P.; Cappa, F.; Spaccini, R.; Piccolo, A.; Trevisan, M.; Crecchio, C. Effects of a humic acid and its size-fractions on the bacterial community of soil rhizosphere under maize (Zea mays L.). Chemosphere 2009, 77, 829-837. [CrossRef]

202. Trevisan, S.; Francioso, O.; Quaggiotti, S.; Nardi, S. Humic substances biological activity at the plant-soil interface: From environmental aspects to molecular factors. Plant Signal. Behav. 2010, 5, 635-643. [CrossRef] [PubMed] 
203. Hamman, B.; Koning, G.; van de Venter, H.A. Cell-wall extension as a mode of action of coal-derived humates. S. Afr. J. Bot. 1999, 65, 197-202. [CrossRef]

204. Elmongy, M.S.; Zhou, H.; Cao, Y.; Liu, B.; Xia, Y. The effect of humic acid on endogenous hormone levels and antioxidant enzyme activity during in vitro rooting of evergreen azalea. Sci. Hortic. 2018, 227, 234-243. [CrossRef]

205. Galambos, N.; Compant, S.; Moretto, M.; Sicher, C.; Puopolo, G.; Wäckers, F.; Sessitsch, A.; Pertot, I.; Perazzolli, M. Humic acid enhances the growth of tomato promoted by endophytic bacterial strains through the activation of hormone-, growth-, and transcription-related processes. Front. Plant Sci. 2020, 11, 582267. [CrossRef] [PubMed]

206. Shah, Z.H.; Rehman, H.M.; Akhtar, T.; Alsamadany, H.; Hamooh, B.T.; Mujtaba, T.; Daur, I.; Al Zahrani, Y.; Alzahrani, H.A.S.; Ali, S.; et al. Humic substances: Determining potential molecular regulatory processes in plants. Front. Plant Sci. 2018, 9, 263. [CrossRef]

207. Adani, F.; Spagnol, M.; Genevini, P. Biochemical origin and refractory properties of humic acid extracted from the maize plant. Biogeochemistry 2006, 78, 85-96. [CrossRef]

208. Widhalm, J.R.; Jaini, R.; Morgan, J.A.; Dudareva, N. Rethinking how volatiles are released from plant cells. Trends Plant Sci. 2015, 20, 545-550. [CrossRef] [PubMed]

209. Senesi, N.; Plaza, C.; Brunettia, G.; Polo, A. A comparative survey of recent results on humic-like fractions in organic amendments and effects on native soil humic substances. Soil Biol. Biochem. 2007, 39, 1244-1262. [CrossRef]

210. Olaetxea, M.; De Hita, D.; Garcia, A.; Fuentes, M.; Baigorri, R.; Mora, V.; Garica, M.; Urrutia, O.; Erro, J.; Zamarreño, A.M.; et al. Hypothetical framework integrating the main mechanisms involved in the promoting action of rhizospheric humic substances on plant root- and shoot-growth. Appl. Soil Ecol. 2018, 123, 521-537. [CrossRef]

211. Olk, D.C.; Bloom, P.R.; Perdue, E.M.; McKnight, D.M.; Chen, Y.; Farenhorst, A.; Harir, M. Environmental and agricultural relevance of humic fractions extracted by alkali from soils and natural waters. J. Environ. Qual. 2019, 48, 217-232. [CrossRef]

212. Perminova, I.V.; García-Mina, J.-M.; Knicker, H.; Miano, T. Humic substances and nature-like technologies. Learning from nature: Understanding humic substances structures and interactions for the development of environmentally friendly, nature-like technologies. J. Soils Sediments 2019, 19, 2663-2664. [CrossRef]

213. Bezuglova, O.S.; Gorovtsov, A.V.; Polienko, E.A.; Zinchenko, V.E.; Grinko, A.V.; Lykhman, V.A.; Dubinina, M.N.; Demidov, A. Effect of humic preparation on winter wheat productivity and rhizosphere microbial community under herbicide-induced stress. J. Soils Sediments 2019, 19, 2665-2675. [CrossRef]

214. Santos, L.F.; Olivares, F.L. Plant microbiome structure and benefits for sustainable agriculture. Curr. Plant Biol. 2021, 26, 100198. [CrossRef]

215. Nardi, S.; Pizzeghello, D.; Muscolo, A.; Vianello, A. Physiological effects of humic substances on higher plants. Soil Biol. Biochem. 2002, 34, 1527-1536. [CrossRef]

216. Mora, V.; Bacaicoa, E.; Zamarreño, A.M.; Aguirre, E.; Garnica, M.; Fuentes, M.; GarcíaMina, J.M. Action of humic acid on promotion of cucumber shoot growth involves nitrate-related changes associated with the root-to-shoot distribution of cytokinins, polyamines and mineral nutrients. J. Plant Physiol. 2010, 167, 633-642. [CrossRef]

217. García, A.C.; Souza, L.G.A.; Pereira, M.G.; Castro, R.N.; García-Mina, J.M.; Zonta, E.; Lisboa, F.J.G.; Berbara, R.L.L. Structureproperty-function relationship in humic substances to explain the biological activity in plants. Sci. Rep. 2016, 6, 20798. [CrossRef]

218. Jindo, K.; Olivares, F.L.; Malcher, D.J.P.; Sánchez-Monedero, M.A.; Kempenaar, C.; Canellas, L.P. From lab to field: Role of humic substances under open-field and greenhouse conditions as biostimulant and biocontrol agent. Front. Plant Sci. 2020, 11, 426. [CrossRef] [PubMed]

219. Elmongy, M.S.; Wang, X.; Zhou, H.; Xia, Y. Humic acid and auxins induced metabolic changes and differential gene expression during adventitious root development in azalea microshoots. HortScience 2020, 55, 926-935. [CrossRef]

220. García, A.C.; Castro, T.A.V.T.; Santos, L.A.; Tavares, O.C.H.; Castro, R.N.; Berbara, R.L.L.; García-Mina, J.M. Structure-propertyfunction relationship of humic substances in modulating the root growth of plants: A review. J. Environ. Qual. 2019, 48, 1622-1632. [CrossRef]

221. Castro, T.A.V.T.; Berbara, R.L.L.; Tavares, O.C.H.; da Graça Mello, D.F.; Pereira, E.G.; da Costa Barros de Souza, C.; Espinosa, L.M.; García, A.C. Humic acids induce a eustress state via photosynthesis and nitrogen metabolism leading to a root growth improvement in rice plants. Plant Physiol. Biochem. 2021, 162, 171-184. [CrossRef]

222. Park, S.; Kim, K.S.; Kim, J.-T.; Kang, D.; Sung, K. Effects of humic acid on phytodegradation of petroleum hydrocarbons in soil simultaneously contaminated with heavy metals. J. Environ. Sci. 2011, 23, 2034-2041. [CrossRef]

223. Chen, M.; Xu, P.; Zeng, G.; Yang, C.; Huang, D.; Zhang, J. Bioremediation of soils contaminated with polycyclic aromatic hydrocarbons, petroleum, pesticides, chlorophenols and heavy metals by composting: Applications, microbes and future research needs. Biotechnol. Adv. 2015, 33, 745-755. [CrossRef] [PubMed]

224. Pukalchik, M.; Mercl, F.; Panova, M.; Břendová, K.; Terekhova, V.A.; Tlustoš, P. The improvement of multi-contaminated sandy loam soil chemical and biological properties by the biochar, wood ash, and humic substances amendments. Environ. Pollut. 2017, 229, 516-524. [CrossRef] [PubMed]

225. Wang, X.; Zheng, J.; Han, Z.; Chen, H. Bioremediation of crude oil-contaminated soil by hydrocarbon-degrading microorganisms immobilized on humic acid-modified biofuel ash. J. Chem. Technol. Biotechnol. 2019, 94, 1904-1912. [CrossRef]

226. Da Silva, I.G.S.; de Almeida, F.C.G.; da Rocha e Silva, N.M.P.; Casazza, A.A.; Converti, A.; Sarubbo, L.A. Soil bioremediation: Overview of technologies and trends. Energies 2020, 13, 4664. [CrossRef] 
227. Tang, Y.; Li, X.; Dong, B.; Huang, J.; Wei, Y.; Dai, X.; Dai, L. Effect of aromatic repolymerization of humic acid-like fraction on digestate phytotoxicity reduction during high-solid anaerobic digestion for stabilization treatment of sewage sludge. Water Res. 2018, 143, 436-444. [CrossRef]

228. Coles, C.A.; Yong, R.N. Humic acid properties and implications for treatment of wastewater containing metals. In GeoEnvironmental Engineering: Integrated Management of Groundwater and Contaminated Land; Yong, R.N., Thomas, H.R., Eds.; British Geotechnical Association: Cardiff, UK, 2004; pp. 29-36. [CrossRef]

229. Kochany, J.; Lipczynska-Kochany, E. Fenton reaction in the presence of humates. Treatment of highly contaminated wastewater at neutral pH. Environ. Technol. 2007, 28, 1007-1013. [CrossRef]

230. Tang, K.; Casas, M.E.; Ooi, G.T.H.; Kaarsholm, K.M.S.; Bester, K.; Andersen, H.R. Influence of humic acid addition on the degradation of pharmaceuticals by biofilms in effluent wastewater. Int. J. Hyg. Environ. Health 2017, 220, 604-610. [CrossRef]

231. Sun, Z.; Tang, B.; Xie, H. Treatment of waste gases by humic acid. Energy Fuels 2015, 29, 1269-1278. [CrossRef]

232. Bearden, B.N.; Petersen, L. Influence of arbuscular mycorrhizal fungi on soil structure and aggregate stability of a vertisol. Plant Soil 2000, 218, 173-183. [CrossRef]

233. Medina, A.; Roldán, R.; Azcón, R. The effectiveness of arbuscular-mycorrhizal fungi and Aspergillus niger or Phanerochaete chrysosporium treated organic amendments from olive residues upon plant growth in a semi-arid degraded soil. J. Environ. Manag. 2010, 91, 2547-2553. [CrossRef]

234. McAllister, C.B.; Garcia-Romera, I.; Martin, J.; Godeas, A.; Ocampo, J.A. Interaction between Aspergillus niger van Tiegh. and Glomus mosseae (Nicol. \& Gerd.) Gerd. \& Trappe. New Phytol. 1995, 129, 309-316.

235. Phillips, R.P.; Brzostek, E.; Midgley, M.G. The mycorrhizal-associated nutrient economy: A new framework for predicting carbon-nutrient couplings in temperate forests. New Phytol. 2013, 199, 41-51. [CrossRef]

236. Hou, W.; Lian, B.; Dong, H.; Jiang, H.; Wu, X. Distinguishing ectomycorrhizal and saprophytic fungi using carbon and nitrogen isotopic compositions. Geosci. Front. 2012, 3, 351-356. [CrossRef]

237. Almonacid, L.; Fuentes, A.; Ortiz, J.; Salas, C.; Garcia-Romera, I.; Ocampo, J.; Arriagada, C. Effect of mixing soil saprophytic fungi with organic residues on the response of Solanum lycopersicum to arbuscular mycorrhizal fungi. Soil Use Manag. 2015, 31, 155-164. [CrossRef]

238. Lagos, C.; Larsen, J.; Fuentes, A.; Herrera, H.; García-Romera, I.; Campos-Vargas, R.; Arriagada, C. Inoculation of Triticum aestivum L. (Poaceae) with plant-growth-promoting fungi alleviates plant oxidative stress and enhances phenanthrene dissipation in soil. Agronomy 2021, 11, 411. [CrossRef]

239. Hedden, P.; Sponsel, V. A century of gibberellin research. J. Plant Growth Regul. 2015, 34, 740-760. [CrossRef]

240. Gusmiaty, M.R.A.; Payangan, R.Y. Production of IAA (indole acetic acid) of the rhizosphere fungus in the Suren community forest stand. IOP Conference Series: Earth Environ. Sci. 2019, 343, 012058. [CrossRef]

241. Kumla, J.; Suwannarach, N.; Matsui, K.; Lumyong, S. Biosynthetic pathway of indole-3-acetic acid in ectomycorrhizal fungi collected from northern Thailand. PLoS ONE 2020, 15, e0227478. [CrossRef]

242. Leontovyčová, H.; Trdá, L.; Dobrev, P.I.; Šašek, V.; Gay, L.; Balesdent, M.H.; Burketová, L. Auxin biosynthesis in the phytopathogenic fungus Leptosphaeria maculans is associated with enhanced transcription of indole-3-pyruvate decarboxylase LmIPDC2 and tryptophan aminotransferase LmTAM1. Res. Microbiol. 2020, 171, 174-184. [CrossRef]

243. Santoyo, G.; Moreno-Hagelsieb, G.; Orozco-Mosqueda, M.C.; Glick, B.R. Plant growth-promoting bacterial endophytes. Microbiol. Res. 2016, 183, 92-99. [CrossRef]

244. Saldajeno, M.G.B.; Hyakumachi, M. Arbuscular mycorrhizal interactions with rhizobacteria or saprotrophic fungi and its implications to biological control of plant diseases. In Mycorrhizal Fungi: Soil, Agriculture and Environmental Implications; Fulton, S.M., Ed.; Nova Science Publishers: New York, NY, USA, 2011; pp. 187-212.

245. Lugtenberg, B.; Kamilova, F. Plant-growth-promoting rhizobacteria. Annu. Rev. Microbiol. 2009, 63, 541-556. [CrossRef]

246. Glick, B.R. Using soil bacteria to facilitate phytoremediation. Biotechnol. Adv. 2010, 28, 367-374. [CrossRef] [PubMed]

247. Glick, B.R. Plant growth-promoting bacteria: Mechanisms and applications. Scientifca 2012, 2012, 963401. [CrossRef] [PubMed]

248. Bais, H.P.; Weir, T.L.; Perry, L.G.; Gilroy, S.; Vivanco, J.M. The role of root exudates in rhizosphere interactions with plants and other organisms. Annu. Rev. Plant Biol. 2006, 57, 233-266. [CrossRef] [PubMed]

249. Begum, N.; Qin, C.; Ahanger, M.A.; Raza, S.; Khan, M.I.; Ashraf, M.; Ahmed, N.; Zhang, L. Role of arbuscular mycorrhizal fungi in plant growth regulation: Implications in abiotic stress tolerance. Front. Plant Sci. 2019, 10, 1068. [CrossRef] [PubMed]

250. Frey, S.D. Mycorrhizal fungi as mediators of soil organic matter dynamics. Annu. Rev. Ecol. Evol. Syst. 2019, 50, 237-259. [CrossRef]

251. Saleem, M.; Hu, J.; Jousset, A. More than the sum of its parts: Microbiome biodiversity as a driver of plant growth and soil health. Annu. Rev. Ecol. Evol. Syst. 2019, 50, 145-168. [CrossRef]

252. Shi, K.; Liu, Y.; Chen, P.; Li, Y. Contribution of lignin peroxidase, manganese peroxidase, and laccase in lignite degradation by mixed white-rot fungi. Waste Biomass Valoriz. 2021, 12, 3753-3763. [CrossRef]

253. Feng, X.; Sun, J.; Xie, Y. Degradation of Shanxi lignite by Trichoderma citrinoviride. Fuel 2021, 291, 120204. [CrossRef]

254. He, W.; Megharaj, M.; Subashchandrabose, S.R.; Wu, C.-Y.; Dai, C.-C. Endophyte-assisted phytoremediation: Mechanisms and current application strategies for soil mixed pollutants. Crit. Rev. Biotechnol. 2020, 40, 31-45. [CrossRef] [PubMed]

255. Lukešová, A. Soil Algae in brown coal and lignite post-mining areas in central Europe (Czech Republic and Germany). Restor. Ecol. 2001, 9, 341-350. [CrossRef] 
256. Chamizo, S.; Mugnai, G.; Rossi, F.; Certini, G.; De Philippis, R. Cyanobacteria inoculation improves soil stability and fertility on different textured soils: Gaining insights for applicability in soil restoration. Front. Environ. Sci. 2018, 6, 49. [CrossRef]

257. Condron, L.; Stark, C.; O'Callaghan, M.; Clinton, P.; Huang, Z. The role of microbial communities in the formation and decomposition of soil organic matter. In Soil Microbiology and Sustainable Crop Production; Dixon, G.R., Tilston, E.L., Eds.; Springer: Dordrecht, The Netherlands, 2010; pp. 81-118. [CrossRef]

258. Misz-Kennan, M.; Fabiańska, M.J. Application of organic petrology and geochemistry to coal waste studies. Int. J. Coal Geol. 2011, 88, 1-23. [CrossRef]

259. Gargallo-Garriga, A.; Preece, C.; Urban, O.; Sardans, J.; Oravec, M.; Peñuelas, J. Root exudate metabolomes change under drought and show limited capacity for recovery. Sci. Rep. 2018, 8, 12696. [CrossRef] [PubMed]

260. Furey, G.N.; Tilman, D. Plant biodiversity and the regeneration of soil fertility. Proc. Natl. Acad. Sci. USA 2021, 118, e2111321118. [CrossRef] [PubMed]

261. Niu, Q.; Meng, Q.; Yang, H.; Wang, Y.; Li, X.; Li, G.; Li, Q. Humification process and mechanisms investigated by Fenton-like reaction and laccase functional expression during composting. Bioresour. Technol. 2021, 341, 125906. [CrossRef] [PubMed]

262. Köbö, K. Microbiological studies on the humification process (Part 1). Effect of microbes on the transformation. Soil Sci. Plant Nutr. 1955, 1, 53-54. [CrossRef]

263. Köbö, K.; Takai, Y. Microbiological studies on the humification process (Part 2). On the aerobic decomposition of the fresh plant residue in the case of single inoculation. Soil Sci. Plant Nutr. 1955, 1, 55-56. [CrossRef]

264. Terrer, C.; Phillips, R.P.; Hungate, B.A.; Rosende, J.; Pett-Ridge, J.; Craig, M.E.; van Groenigen, K.J.; Keenan, T.F.; Sulman, B.N.; Stocker, B.D.; et al. A trade-off between plant and soil carbon storage under elevated $\mathrm{CO}_{2}$. Nature 2021, 591, 599-603. [CrossRef]

265. Bastos, A.; Fleischer, K. Fungi are key to $\mathrm{CO}_{2}$ response of soil. Nature 2021, 591, 532-534. [CrossRef] 